\title{
Taxonomic and non-taxonomic responses of benthic macroinvertebrates to metal toxicity in tropical reservoirs. The case of Cantareira Complex, São Paulo, Brazil
}

\author{
FREDERICO G.S. BEGHELLI, MAURÍCIO CETRA, MERCEDES MARCHESE, \\ JÚLIO CÉSAR LÓPEZ-DOVÁL, ANDRÉ H. ROSA, MARCELO LUIZ M. POMPÊO \& \\ VIVIANE MOSCHINI-CARLOS
}

\begin{abstract}
Benthic macroinvertebrates are organisms that are recognized as water quality bio-indicators. A wide variety of indices and metrics have been shown to respond to a variety of anthropogenic impacts, usually under a general condition of environmental impairment. The absence of a clear distinction in the relations between specific pollutants and biotic variables is very common and can lead to biased interpretation of biomonitoring. The aims of this research were to test taxonomic and non-taxonomic responses to specific environmental conditions instead to general conditions. For this purpose, we estimated the theoretical toxicity by comparing toxicity values published by EPA with metal concentrations in water and sediments. Then we tested the responses of biological variables to toxicity and other environmental conditions using the linear mixed effects models approach. We generated 32 models considering 24 different biological metrics and indices that were grouped in five levels. Taxonomic and abundance metrics were best predictor than functional or tolerance-based indexes. The strongest model was that which considered subfamily taxonomic resolution responding to Al_w and Cr_S.
\end{abstract}

Key words: bio-indicator, biomonitoring, chironomid, oligochaetes, toxicity, metal.

\section{INTRODUCTION}

The assemblage of benthic macroinvertebrates (BMI) is made up of heterotrophic macroscopic organisms, which have a direct relation with sediments. In general, these organisms have low mobility and are primarily detritivores (Carvalho \& Uieda 2009). BMI are fundamental to the maintenance of aquatic ecosystems because they recover matter from sediment debris (Frauendorf et al. 2013, Whiting et al. 2011). BMI promote sediment oxygenation through bioturbation, which in turn affects biogeochemical cycles (Puigagut et al. 2014, Shang et al. 2014).
These organisms are widely used as bioindicators in continental waters (CzerniawskaKusza 2005, Zilli et al. 2008, Azevêdo et al. 2015, Erba et al. 2015, Damanik-Ambarita et al. 2016) because they have many characteristics that are desirable in a bio-indicator. BMI are widely distributed throughout virtually every aquatic ecosystem (Bonada et al. 2006). Their low mobility means that BMI cannot escape from any damaging agents, and this characteristic permits us to identify environmental gradients in pollution (Beghelli et al. 2014) or other gradients of change, for example (Brand \& Miserendino 2015). Furthermore, BMI rapidly 
respond to environmental alterations, and they include a wide variety of organisms with distinct ranges of tolerance to pollutants (Mandaville 2002, Bonada et al. 2006).

BMI's relations to sediments lead them to respond to problems that are not usually detectable in water because pollutants tend to accumulate on the bottom over time, especially in lentic systems (Bettinetti et al. 2012). Because of the position of BMI in the food webs, these organisms receive matter from other trophic levels such as phytoplankton (Yu et al. 2013), macrophytes (Silveira et al. 2013), zooplankton (Tang et al. 2014) and riparian vegetation (Scharnweber et al. 2014). Given their position, any stress that occurs in the water, surrounding land or sediments has the potential to cause a BMI response.

Potentially toxic metals are one of the most worrisome pollutants in continental waters (Zhang \& Liu 2014, Schneider et al. 2014, López-Dovál et al. 2015). Attention to these metals is necessary, primarily because they are widely distributed, they are persistent in the environment and they can be bioaccumulated, leading to damage in ecosystems as also to human health (Schwarzenbach et al. 2006, 2010, Bin et al. 2013, Alves et al. 2014, Roig et al. 2016). Furthermore, analytical techniques for determining metals in waters (US-EPA 1992) and sediments (US-EPA 1996) are well-established, and metal toxicity levels are known (US-EPA 1999).

In considering BMI assemblages, there is a vast variety of metrics, indices and taxa that are described as bio-indicators in the literature. Among these measurements, there are classes of indices, namely, the index directly related to diversity (Azevêdo et al. 2015), the proportion of tolerant or sensitive organisms within the assemblage (Beghelli et al. 2012, Clews et al.
2014), the BMI density of organisms, and indices related to functional groups (He et al. 2015).

In addition, the majority of studies that have focused on BMI as bio-indicators were designed to distinguish between damaged and non-damaged areas to relate the general environmental quality to a variety of environmental variables. These studies primarily relate "damaged" or "non-damaged" conditions to the given land use, landscape ecology, organic pollution or general toxicity (Clews et al. 2014, Fanny et al. 2013, Gonçalves \& Menezes 2011). The situation is no different in Brazil, where the use of BMI as bio-indicators is focused within lotic systems (Baptista 2008, Baptista et al. 2007, 2011, 2013, Couceiro et al. 2012, Egler et al. 2012, Ferreira et al. 2011, Mugnai et al. 2008, Junqueira \& Campos 1998, Suriano et al. 2011). Despite the known relevance of reservoirs in Brazil (Tundisi \& Matsumura-Tundisi 2008), there is a clear lack of information about the use of benthic macroinvertebrates as bio-indicators in these environments. As a contribution, the Companhia Ambiental do Estado de São Paulo, or CETESB, developed a multimetric index for littoral benthic macroinvertebrates for reservoirs. This agency tracks the taxa richness, the ShannonWiener index, the dominance of tolerant groups, the number of sensitive taxa and an index of sequential comparison (CETESB 2012).

These studies have made a great contribution to the fields of Ecology and Ecotoxicology, especially in view of the fact that ecosystems are complex and that the biomonitoring of general conditions is necessary. However, approaches that consider specific classes and attempts to isolate the specific effects of distinct pollutants or damaging agents are also desirable to increase our knowledge about their effects in nature and also to better delimit the bio-indicator potential of different organisms. once a general environmental status approach 
is chosen, it is difficult to discriminate among the damaging agents to which the BMI are really responding or if there are any synergistic or competing effects (Zhang \& Liu 2014).

An important contribution was made by Zhang \& Liu (2014), which provided an ecological risk approach to metals through BMI metrics (functional and tolerance measurements). These authors assessed the effects of metal toxicity on benthic macroinvertebrates in Lake Baiyangdian, China along a gradient of human impacts. Studies that take this direction are desirable because they provide an important complement to the more general approach, and because they allow for predictions that are more accurate. Furthermore, distinct analyses of specific climatic regions are also complementary and beneficial.

By testing BMI responses to metal toxicity, taxonomic and non-taxonomic metrics and indices are expected to vary according to the metal toxicity in water and sediments (Zhang \& Liu 2014). Based on this assumption, the present work is premised on the following hypotheses: differential habits and sensibilities may promote distinct responses. Metrics and indices related to the proportion of tolerant groups (i.e., dominance indices and indices based on tolerant taxa) may generally be favored by high toxicity. The taxa density and richness are expected to decrease with increasing toxicity, and a finer taxonomic resolution is expected to be more sensitive than the coarser measurements. Metals that present high theoretical toxicities are also predicted to have a wider influence on BMI assemblages, and various indices and/or metrics can respond distinctly to the toxicity exerted by different elements.

In considering niche theory and its relation to interspecific competition, higher toxicities must promote a decrease in the relative abundance of sensitive groups and an increase in the most tolerant ones. As a result, complementary relations may be observed, with increases in the relative abundance of one group coupled with a decrease in another as a response to the same toxicities (Colas et al. 2014).

The aim of this study was to test the mixed effects of metal toxicity in sediments and water over several BMI assemblages and their responses according to indices and metrics based on distinct levels in the taxonomic resolution, functional indices, abundance and tolerance. With this outlook, we aim to provide models that will generate parameters for use in biomonitoring or future research.

\section{Study area}

The Cantareira Complex is formed by five reservoirs, namely Jaguari, Jacareí, Cachoeira, Atibaia and Paiva Castro, which are linked by tunnels and channels. For practical purposes, Jaguari and Jacareí can be considered as the same reservoir once there is no physical barrier between them. Each reservoir receives water from the former reservoir and from a primary tributary river (Figure 1). Waters from the Cantareira Complex are used to supply the people in the Metropolitan Region of São Paulo (RMSP), Brazil. This complex provides approximately $30 \%$ of the water consumed by 20 million people in the RMSP according to data published by the company that is responsible for water treatment and supply, which is known as the SABESP (SABESP 2015).

The Cantareira Complex is surrounded by an urbanized area that was originally occupied by Atlantic rainy forest. Based on satellite imagery, Whately \& Cunha (2007) concluded that only $21 \%$ of the original forest cover was preserved until 2003. The majority of the Cantareira Complex surroundings was modified into agriculture fields, pasture and abandoned fields. With respect to the area of each reservoir's watershed, 
the highest proportion of natural vegetation (37\%) occurs in the Paiva Castro watershed.

The Jaguari reservoir watershed has 17.7\% natural forest coverage, and Cachoeira has 17.5; Jacareí covers just 11.6\%. Furthermore, regional industrialization, mining activities and the presence of extensive roads are potential sources of damage that may contribute to water quality degradation (Whately \& Cunha 2007).

M.L.M Pompêo et al. (unpublished data) determined the chlorophyll-a (Lorenzen 1967) and total phosphorus (Valderrama 1981) in the Cantareira Complex reservoirs in May and June 2013, at sampling points next to those chosen for the present work. In considering the proximity with the sampling points from the present study, Figure 2 shows the approximate concentrations of
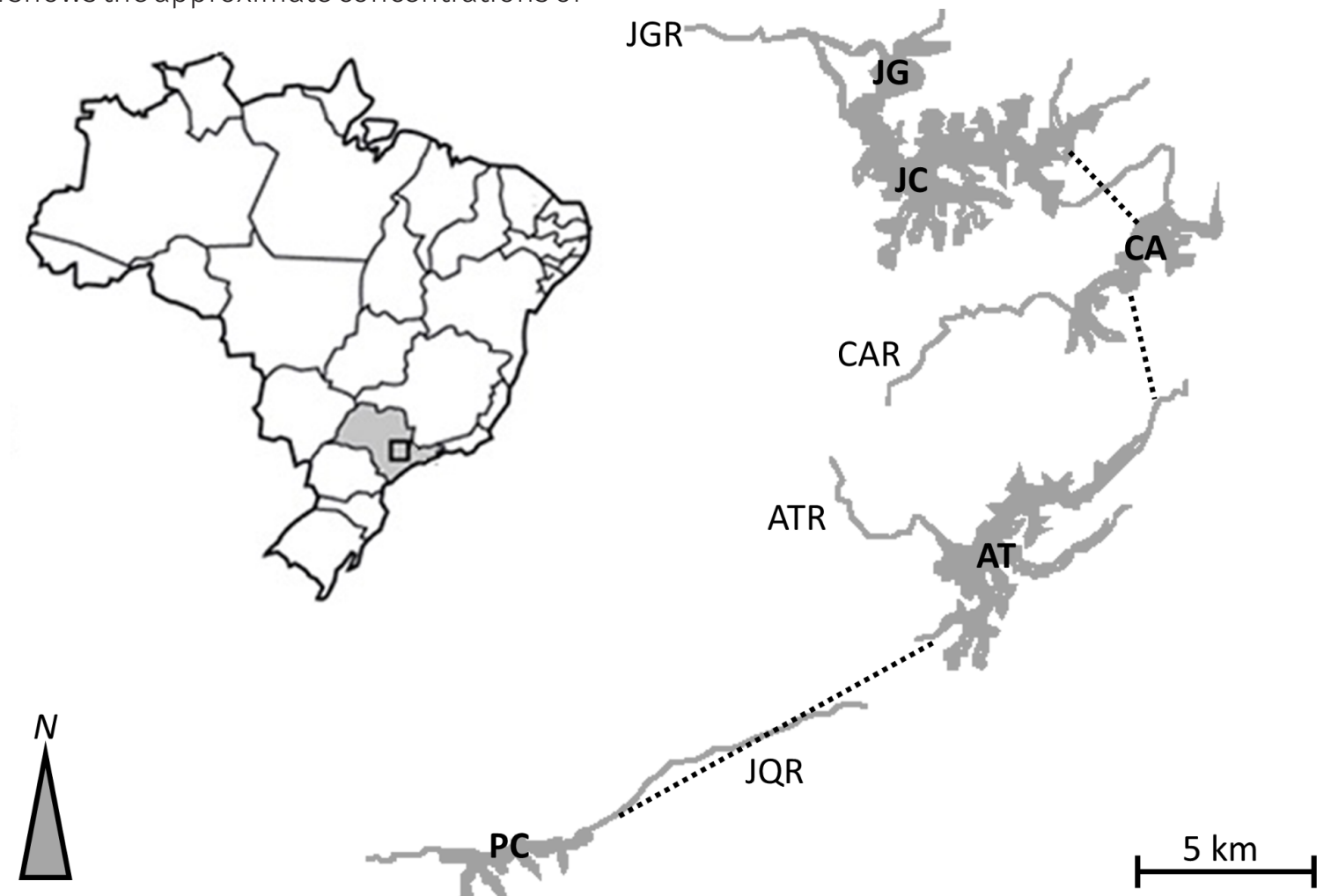

total phosphorus and chlorophyll-a determined by this study, and also the trophic state index by Carlson as adapted by Lamparelli 2004 for tropical reservoirs. These data indicate the oligotrophic state of all of the sampling points during the period. Higher trophic conditions occurred in the Jaguari-Jacareí reservoir.

In relation to the sediment, a recent report by the Companhia Ambiental do Estado de São Paulo, or CETESB for 2014 indicated that acute toxicity occurred in Vibrio fischeri in more than $80 \%$ of the sediment samples from those reservoirs. The sediment toxicity was considered high in more than $50 \%$ of the samples analyzed by CETESB 2015.

Figure 1. (Left) Approximate location of the Cantareira System in São Paulo State, Brazil. (Right) The Cantareira System and its primary tributaries and reservoirs, namely, the Jaguari River (JGR), Cachoeira River (CAR), Atibaia River (ATR), Juqueri River (JQR), Jaguari reservoir (JG), Jacareí reservoir (JC), Cachoeira reservoir (CA), Atibaia reservoir (AT, not included in the present study), and Paiva Castro reservoir (PC). Dashed lines represent the connecting tunnels between the reservoirs. 


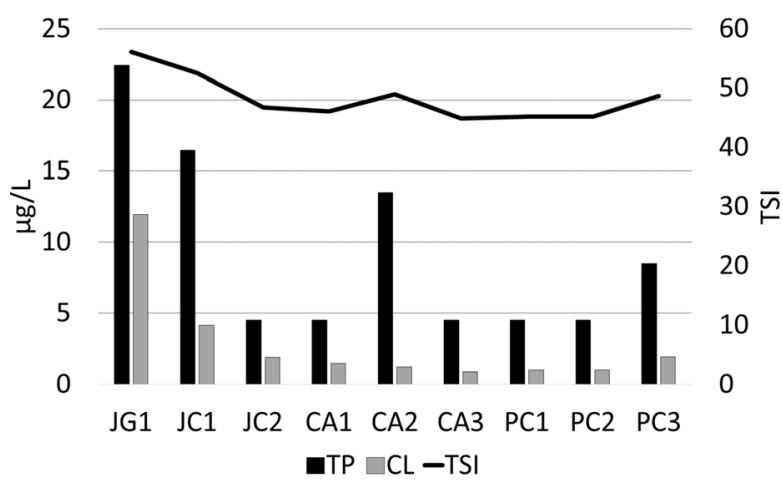

Figure 2. Variables considered here (total phosphorus, TP and chlorophyll-a, CL) to calculate Lamparelli's Trophic State Index (TSI) and the mean TSI. The classification employed definitions of TSI $\leq 47$ ultraoligotrophic $\leq 52$ oligotrophic $\leq 59$ mesotrophic $\leq$ 63 eutrophic $\leq 67$ supereutrophic $\leq$ hypereutrophic.

\section{MATERIALS AND METHODS}

\section{Sampling points}

Samples were collected during July and August, 2013 at three points from a depth of $3 \mathrm{~m}$ (3.23 \pm 0.5) (Table I). The sampling points were distributed along reservoirs that were divided into approximate head, middle and dam regions.

\section{Benthic Macroinvertebrates (BMI)}

Sediments were collected for BMI counting and identification at each sampling point. The BMI sampling was performed by using an Ekman dredge (area $=0.021 \mathrm{~m}^{2}$ ) that was launched three times to make one cumulative sample. The sediment was passed through a $0.2 \mathrm{~mm}$ sieve and preserved in a $4 \%$ formaldehyde solution. Afterwards, the organisms were identified to the genus or species level by using identification keys and manuals (Brinkhurst \& Marchese 1992, Mansur et al. 2004, Marchese 2009, Borkent \& Spinelli 2007, Trivinho-Strixino 2011).

After the taxonomic identifications, taxonomic and non-taxonomic metrics and indices that considered the taxonomic species/ genus, subfamily and family levels, as well as the tolerance, functional and abundance levels were calculated. The multimetric index for sublittoral BMI from CETESB 2012 was calculated as a general regional index specific to reservoirs. Only taxonomic groups that occurred in at least one sample from each reservoir were considered. The biological metrics and indices were organized by category depending on the category in use (taxonomic or non-taxonomic) and by level, depending on the given taxonomic level (Table II).

\section{Sediment}

Three samples (see Table I) from each reservoir were collected (total $=$ nine samples) with an Ekman dredge, and organic and inorganic fractions of coarse (> $212 \mu \mathrm{m})$ and fine sediments were calculated by sieving the dried material. The organic matter content was determined for each fraction by calcination in a muffle furnace at $550{ }^{\circ} \mathrm{C}$ (Wetzel \& Likens 1991). By following these procedures, the fine (FIS) and coarse inorganic (CIS) sediment fractions in addition to fine (FOM) and coarse organic matter (COM) were determined.

To determine the $\mathrm{Al}, \mathrm{As}, \mathrm{Cd}, \mathrm{Cr}, \mathrm{Cu}, \mathrm{Ni}, \mathrm{Pb}$ and $\mathrm{Zn}$ concentrations in the sediment samples, the sample material was dried $\left(40^{\circ} \mathrm{C}\right)$ and then digested in triplicate with $\mathrm{HNO}_{3}, \mathrm{HCl}$ and $\mathrm{H}_{2} \mathrm{O}_{2}$ on a digitally controlled heater plate (Quimis, Q313M) according to method 3050-B (US-EPA 1996). Readings were performed in an ICP-OES (Agilent Technologies 700 Series). Quantification limits were determined according to the equation: $L Q$ $=10 \mathrm{~s} / \alpha$.

\section{Water}

Analyses of the $\mathrm{pH}$, dissolved oxygen (DO) and electric conductance (EC) in the bottom water were performed in situ by using a Horiba U50 multiprobe. The water transparency was measured with a Secchi disk (SD). Samples were 
Table I. Geographic coordinates of sampling points, abbreviations and date.

\begin{tabular}{|c|c|c|c|}
\hline Reservoir & Abbreviation & Coordinates & Date \\
\hline Jacareí & JC1 & $22^{\circ} 57^{\prime} 13.02^{\prime \prime} \mathrm{S} / 46^{\circ} 18^{\prime} 44.47^{\prime \prime} \mathrm{W}$ & $08 / 28 / 2013$ \\
\hline Jacareí & JC2 & $22^{\circ} 58^{\prime} 18.62^{\prime \prime} \mathrm{S} / 46^{\circ} 19^{\prime} 52.27^{\prime \prime} \mathrm{W}$ \\
\hline Jaguari & JG1 & $22^{\circ} 54^{\prime} 45.87^{\prime \prime} \mathrm{S} / 46^{\circ} 24^{\prime} 24.46^{\prime \prime} \mathrm{W}$ & $08 / 14 / 2013$ \\
\hline Cachoeira & CA1 & $23^{\circ} 0^{\prime} 34.68^{\prime \prime} \mathrm{S} / 46^{\circ} 15^{\prime} 19.22^{\prime \prime} \mathrm{W}$ & 0 \\
\hline Cachoeira & CA2 & $23^{\circ} 0^{\prime} 36.63^{\prime \prime} \mathrm{S} / 46^{\circ} 17^{\prime} 8.23^{\prime \prime} \mathrm{W}$ & $07 / 24 / 2013$ \\
\hline Cachoeira & CA3 & $23^{\circ} 4^{\prime} 10.29^{\prime \prime} \mathrm{S} / 46^{\circ} 18^{\prime} 42.81^{\prime \prime} \mathrm{W}$ & $0.92^{\prime \prime} \mathrm{S} / 46^{\circ} 35^{\prime} 42.35^{\prime \prime} \mathrm{W}$ \\
\hline Paiva Castro & PC1 & $23^{\circ} 19^{\prime} 35.37^{\prime \prime} \mathrm{S} / 46^{\circ} 37^{\prime} 23.50^{\prime \prime} \mathrm{W}$ & \\
\hline Paiva Castro & PC2 & $23^{\circ} 19^{\prime} 47.32^{\prime \prime} \mathrm{S} / 46^{\circ} 40^{\prime} 23.57^{\prime \prime} \mathrm{W}$ & \\
\hline Paiva Castro & PC3 & & 07 \\
\hline
\end{tabular}

taken in a Van Dorn bottle to determine the metal concentrations in the water.

The water samples were acidified with $\mathrm{H}_{2} \mathrm{SO}_{4}$ until they reached a $\mathrm{pH}=2$. They were then digested in triplicate with $\mathrm{HNO}_{3}, \mathrm{HCl}$ and $\mathrm{H}_{2} \mathrm{O}_{2}$ on a digitally controlled heater plate according to method 3005a (US-EPA 1992). Readings were performed in an ICP-OES, and the limit of quantification was calculated. Fortified solutions were prepared as checkpoints at concentrations of $0.20,0.50$ and $5.00 \mathrm{mg} / \mathrm{L}$.

\section{Toxicity}

In this work, we considered total concentration of metals in the environment as a practical decision. We do not disagree that metal redox status, complexation or adsorption may interfere in toxicity (Hughes 2002, Flynn et al. 2014). However, such environmental conditions are not stable along the life time of BMI (Miao et al. 2006).

Considering that sediments where benthic macroinvertebrates live works as a pollutant sink, we believe that an approach considering total concentrations must give a more realistic situation of the ecosystem and the organisms experience, instead an instantaneous picture of a short-time situation. Moreover, many of these organisms ingest suspended matter and sediments (Cummins \& Klug 1979, Merrit \& Cummins 1996, Heino 2008). As consequence, $\mathrm{BMI}$ are subjected to toxicity by many pathways. Faunal composition must reflect the sum of distinct situations along time.

The resulting metal concentrations were compared with toxicity reference values for ecological risk assessment (TRV) as calculated on the basis of the lowest effect level, LEL (Persaud et al. 1993) or effects range-low, ERL (Long et al. 1995) approaches depending on the analyzed metal according to US-EPA (1999) recommendations. The TRV considered here are based on toxicity assays that considered the total concentrations of metals. The ERL and LEL are thresholds at which toxic effects are expected to occur occasionally. At ERL, the lower $10^{\text {th }}$ percentile of observable effects in organisms will define the threshold. The LEL is the $5^{\text {th }}$ percentile of the screening level concentration (SLC). According to Persaud et al. 1993, "the SLC is an estimate of the highest concentration of a 


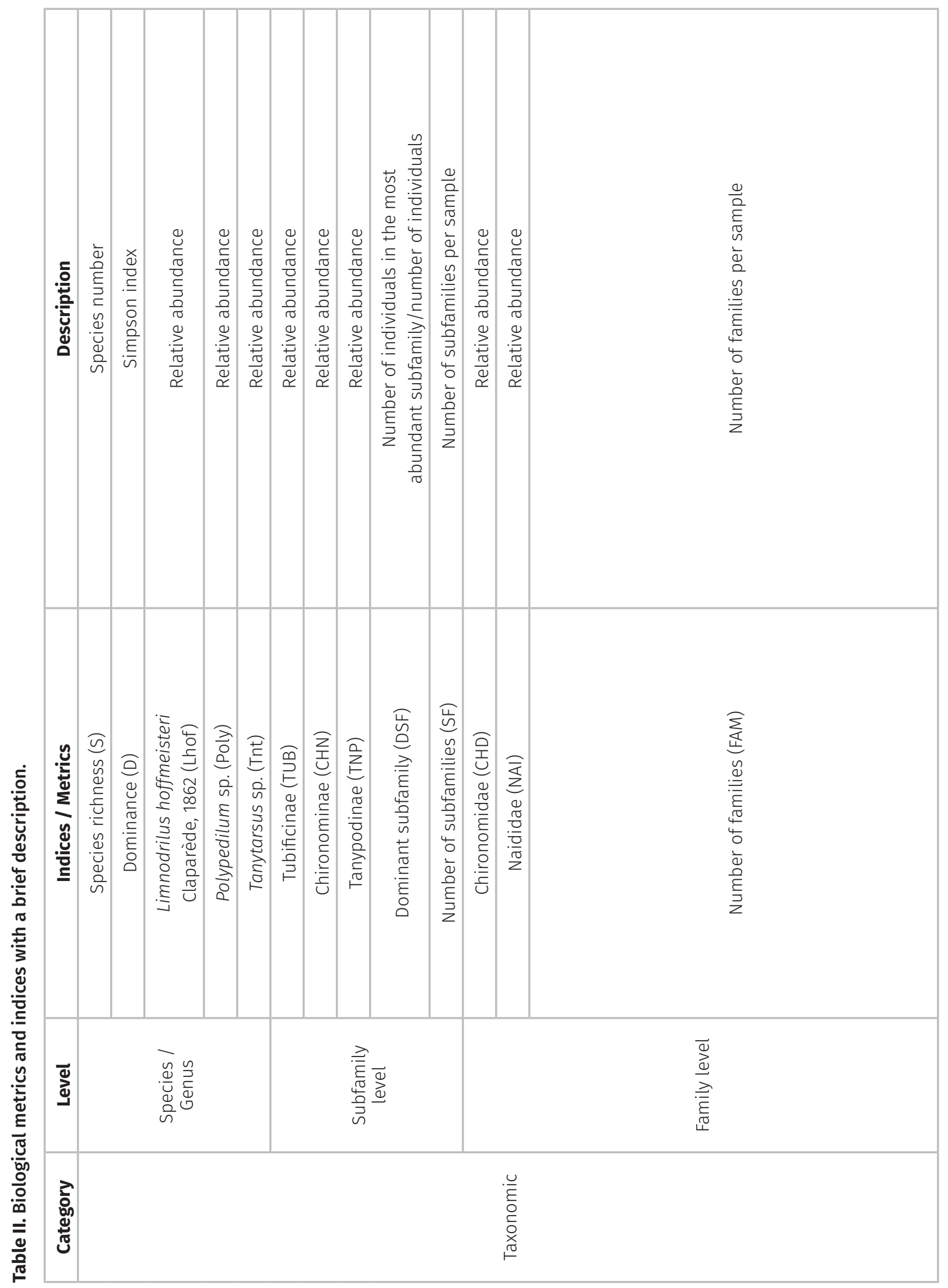




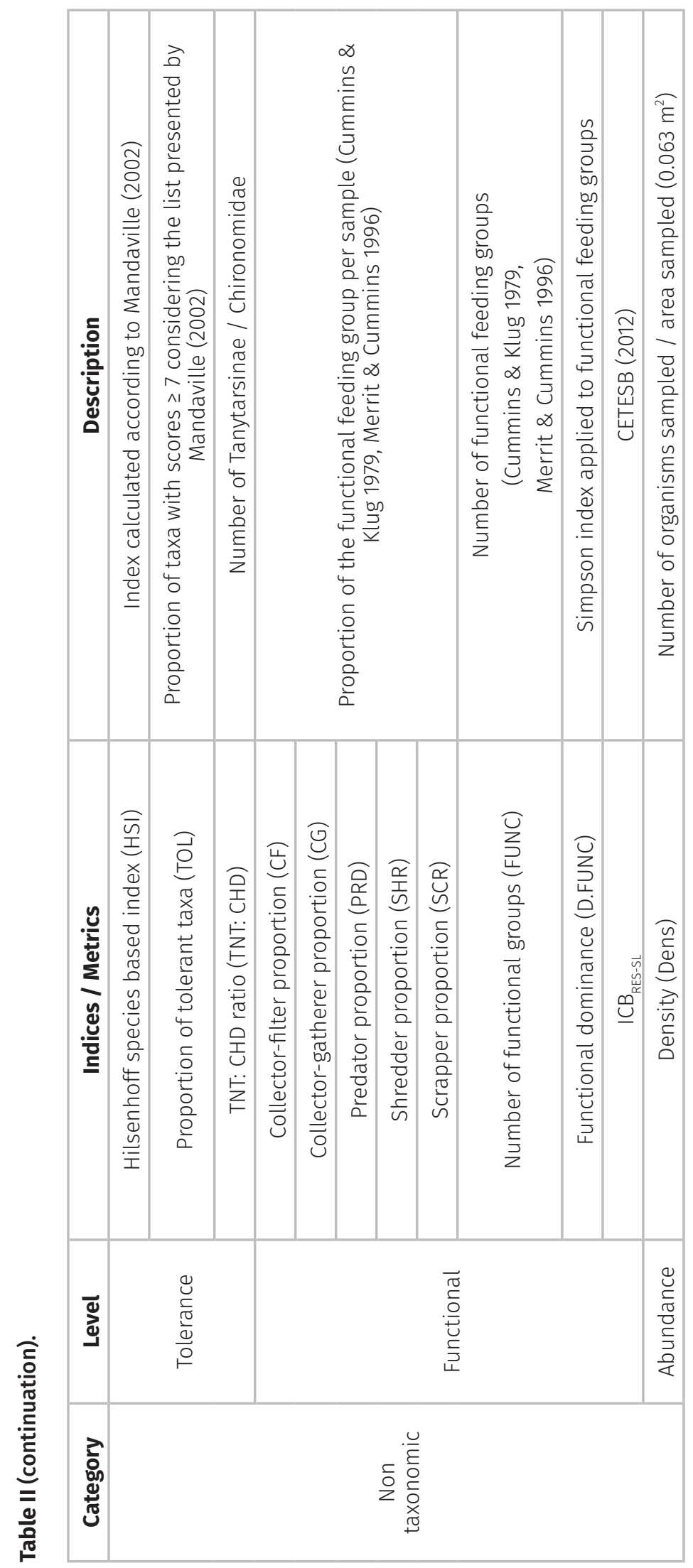

An Acad Bras Cienc (2020) 92(2) e20180962 8| 28 
Table III. Toxicity reference values (TRVs) by toxic unit (TU) determination.

\begin{tabular}{|c|c|c|}
\hline & Sediment $\mathbf{( m g} / \mathbf{k g})$ & Water $\mathbf{( m g / L )}$ \\
\hline $\mathrm{Al}$ & 1400 & 0.087 \\
\hline $\mathrm{As}$ & 6 & 0.15 \\
\hline $\mathrm{Cd}$ & 0.6 & 0.0022 \\
\hline $\mathrm{Cr}$ & 26 & 0.011 \\
\hline $\mathrm{Cu}$ & 16 & 0.009 \\
\hline $\mathrm{Ni}$ & 16 & 0.052 \\
\hline $\mathrm{Pb}$ & 31 & 0.0025 \\
\hline $\mathrm{Cn}$ & 110 & 0.118 \\
\hline
\end{tabular}

*The TRVs are based on US-EPA standards (1999). The TRV for metals in the water were determined by considering the dissolved fraction, with exceptions for Al and As, for which the total concentrations were considered.

contaminant that can be tolerated by a specific proportion of benthic species".

The toxic units (TU) for each metal were then calculated with the equation $T U=M C / T R V$ in accordance with Sprague (1970) and CastroCatalá et al. (2015), with modifications.

Where $M C$ is the concentration of the metal in the sediment or the water sample, and the $T R V$ is the toxicity reference value for that metal. TU values that are higher than this unit indicate toxicity, and the more the TU exceeds this unit, the more toxic the sediment or water under analysis. The TRVs are shown in Table III.

The TRVs are based on US-EPA standards (1999). The TRV for metals in the water were determined by considering the dissolved fraction, with exceptions for Al and As, for which the total concentrations were considered.

TRV values considered here is just used as a reference and selection criteria for models building. They must not be considered as strictly threshold values in our work where total concentrations are measured instead of the dissolved ones. However, as the effects of dissolved concentrations and toxic units are dependent variables of total concentrations, the establishment of conceptual models must not be affected by such imprecision.

\section{Statistical analysis}

Pearson correlations ( $r$ ) were calculated for the metal concentrations, and only metals that were not correlated could be entered into the models $(r<0.70)$. When a correlation was observed, the metal with the highest toxicity among all of the samples was chosen to use in the model to avoid autocorrelation.

Once the literature showed that the biological variables used here can respond to eutrophication, t-tests were performed between the dataset of biological variables against the total phosphorus (TP), chlorophyll-a (CL) and trophic state index (TSI) to check if alterations in these variables could influence the biological responses.

A group of environmental variables that were not directly related to metal toxicity are included, namely the pH, DO, EC, SD, FOM, COM, FIS and CIS. These measurements reflect the sediment composition, water physical-chemical conditions and trophic state in a broad sense. A Principal Component Analysis was performed by using these variables that were previously standardized as z-scores. This analysis was performed with the aim of including the environmental gradient, which is known here as "neutral", in the models with metal toxicities. 
To perform this analysis, the eigenvalues from principal component 1 (PC1) were considered. The scores of PC1 from this PCA is called here as ENV component.

Biological data were resumed into five components representing the five biological levels on Table I plus abundance. Transformation procedures were like those described for ENV variables. As a result, models considered variations in biological levels (Species, Subfamily, Family, Tolerance, Function and Abundance) as a response to ENV and to metal toxicities.

The z-score standardization avoids the attribution of different weights based on the range of variation for each variable. With such procedure, the recorded value for each case (considered separately by variable) is transformed in terms of deviance of the mean. Considering this, z-score transformations remove the effect of greater abundance of some dominant species and permits the comparison in terms of variability and distribution.

Conceptual models were obtained by using a linear mixed effects approach. Linear mixed effects models include both random and fixed predictors, and they are recommended when working with block or nested designs. In the present work, each reservoir was considered as a block that could exert some random effects on a dependent variable (biological data), and the intrinsic variations that were promoted by the reservoir effects were therefore not neglected in the models (Zuur et al. 2009, Logan 2010).

The models were selected by using information theory with Akaike Information Criteria (AIC). From a broad view, AIC measures the loss of information that occurs when choosing any given model in relation to the full reality. Models with smaller AIC values are then indicative of a higher fidelity to the full reality and are initially considered as the "best hypothesis".
Important measures of the strength of a competing model are derived from the $\triangle \mathrm{AIC}$ (the difference between the "best hypothesis" and any other competing model). One is the probability of a model ( $w, 0-1)$, which measures the strength of the evidence. Another is the evidence ratio $\left(\mathrm{w} / \mathrm{w}_{0}\right)$, which provides information about "how many times" one model is better than another one. A comparison of the best model ( $w$, the selected model) against a reduced model ( $w_{0}$, the model without any predictor variables but with only the intercept constant) will demonstrate how strong the selected model is. For more details about statistics based on information theory and criteria for model selection based on the I-T approach, see Burnham et al. (2011).

In the present work, we selected the six best models to explain variations in $\mathrm{BMI}$ indices and metrics grouped by levels by considering taxonomic measures with coarse and fine resolution in addition to non-taxonomic measures (functional, tolerance-based and abundance measures) based on sediment and bottom water characterization with an emphasis on the role of metal pollution.

For each biological variable listed in Table $V$, a full model containing the neutral gradient and all metals with a TU $>1$ without correlations between them was generated. From this full model, the other 31 were generated and compared, including the reduced one. A total of 192 models were generated.

The selection of the best model for each biological level was based on the AIC and the importance $\left(i_{v}\right)$ of the variables (i.e., the proportion at which one predictor variable was significant for explaining the descriptor variable by considering the 32 models that were generated) by using the following criteria:

1) Only variables with $\left(i_{v}\right) \geq 0.50$ were considered. 


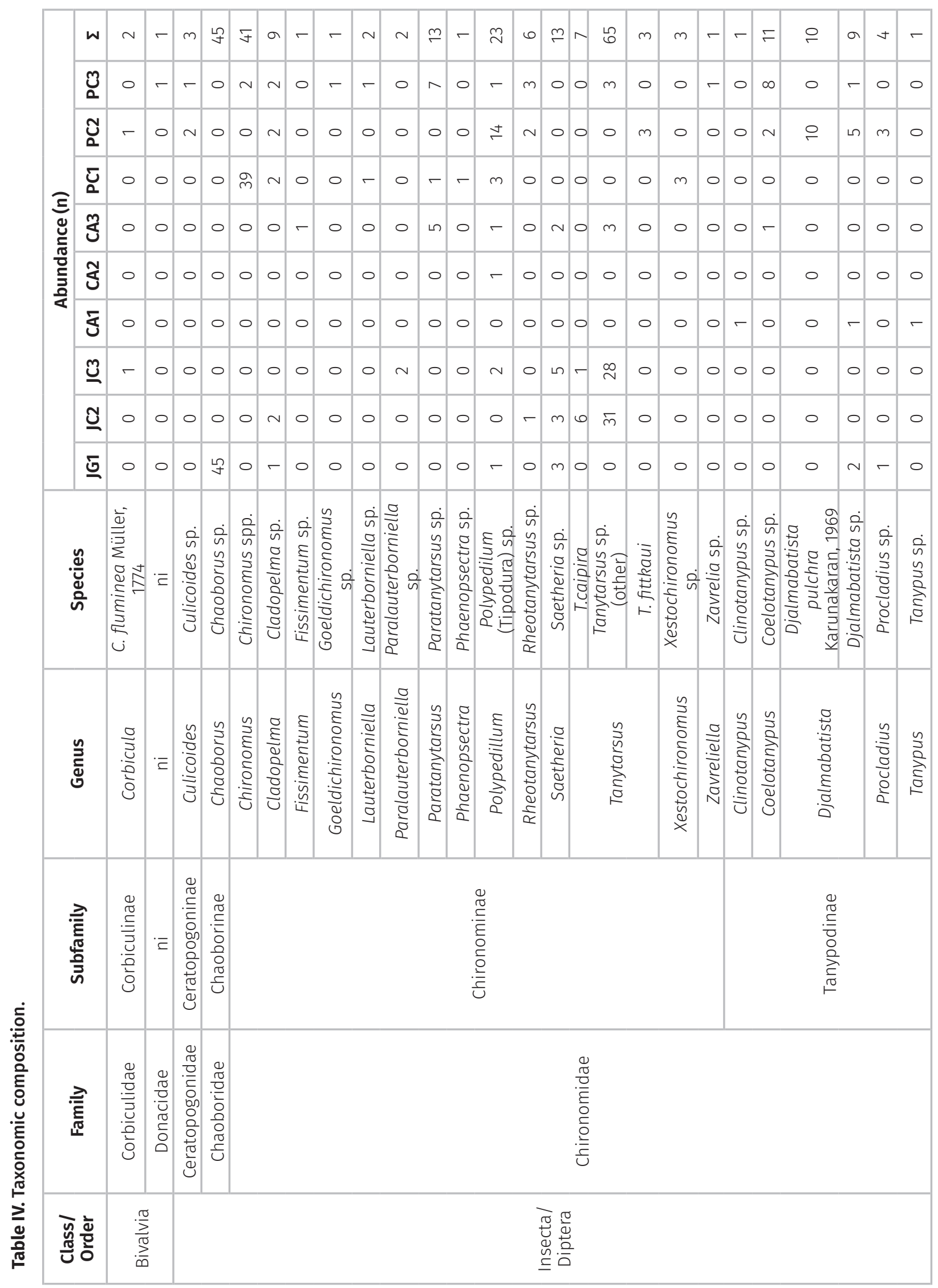




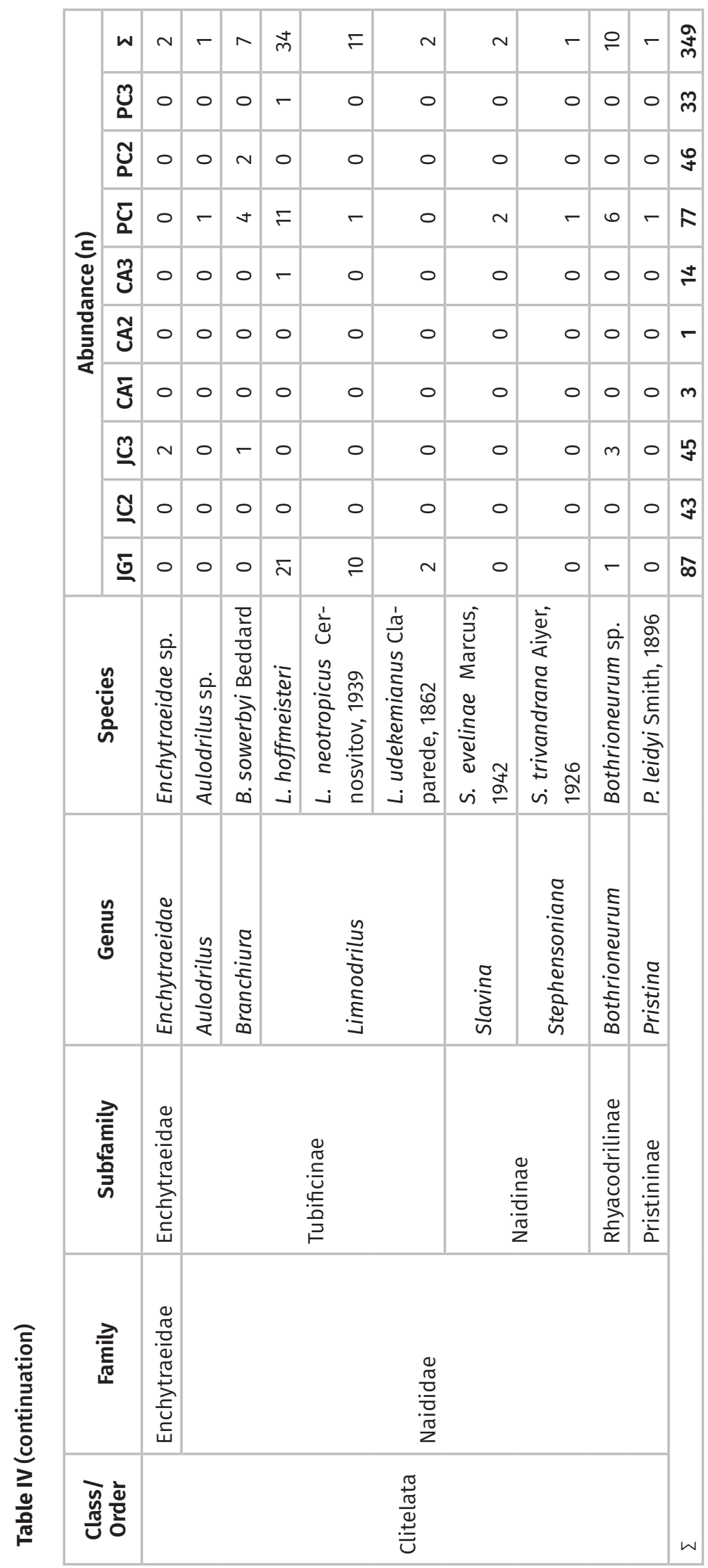

An Acad Bras Cienc (2020) 92(2) e20180962 12 | 28 
2) The best model is preferably the one that includes all variables with $\left(i_{v}\right) \geq 0.50$.

3) The evidence ratio that compares the best model according to criteria (1) and (2) with the reduced model must be at least 2.0 to be considered "significant". This criterion indicates that the selected model is at least twice as strong as a random distribution (the reduced model).

The mean $\left(i_{v}\right)$ values were calculated for each predictor variable by considering the selected models as a general measure of the importance of each environmental component in the BMI assemblage.

\section{RESULTS}

\section{BMI assemblage}

In checking every sample, 36 species belonging to eleven subfamilies and seven families were identified. From this identification, only three species, two subfamilies and two families were collected from the three reservoirs. Chironomidae and Naididae were the most representative taxonomic families, and Chironominae, Tanypodinae (Chironomidae) and Tubificinae (Naididae) were the subfamilies that could be selected according to the occurrence criteria. The chironomids Polypedilum sp. and Tanytarsus sp and the tubificid L. hoffmeisteri were the most representative species.

There were up to five taxonomic subfamilies per sample. Only one subfamily was recorded in JC2, CA1 and CA2. The quantitative results were the same when comparing the number of subfamilies with the number of families per sample. Despite this finding, the composition was not the same (i.e., families comprised more than one subfamily, but in general, only one was distributed around all three reservoirs according to our selection criteria).
Polypedilum sp. was predominant in Cachoeira samples, and Tanytarsus spp. prevailed in Jaguari-Jacareí. L. hoffmeisteri has intermediary relative abundance in the JaguariJacareí and Paiva Castro reservoirs. Lower density values were recorded in samples from Cachoeira (96 ind $/ \mathrm{m}^{2} \pm 112$ ). Paiva Castro (833 \pm 362) and Jaguari-Jacareí (935 \pm 398) were similar in relation to the density of organisms. A higher number of species occurred in Paiva Castro (1115) than in Jaguari-Jacareí (5-10), and the lowest values were recorded in the Cachoeira samples (1-7). The species dominance followed a gradient of $\mathrm{PC}<\mathrm{JG}-\mathrm{JC}<\mathrm{CA}$. Taxonomic composition and abundance are showed in Table IV.

The functional feeding groups known as collector-filters (mean $=30 \% \pm 35$ ), predators $(27 \% \pm 35)$ and collector-gatherers $(26 \% \pm 29)$ were predominant, and they had similar relative abundances per sampling point. However, their distribution was distinct. The predator guild was predominant at JG-JC, the collector-filterers dominated CA and the collector-gatherers were better represented in PC. A higher number of functional groups was observed in the $P C$ samples (Table V).

In selecting for a score $\geq 7$ (Mandaville 2002), the following genus/species were considered as tolerant: a Donacidae that was not identified (ni.); Culicoides sp. ; Chaoborus sp. ; Chironomus spp.; Fissimentum sp.; Goeldichironomus sp; Lauterborniella sp.; Zavrelia sp.; Coelotanypus sp.; Djalmabatista pulchra Johannsen, 1908; Djalmabatista sp.; Procladius sp.; Tanypus sp.; Enchytraeidae; Branchiura sowerbyi Beddard, 1892; L. hoffmeisteri and Limnodrilus neotropicus Cernosvitov, 1939.

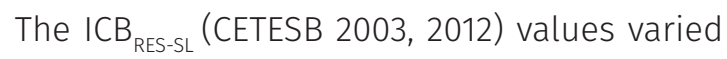
from 2.50 to 3.25 . This variation is not significant when considering the classification proposed by CETESB (2012). According to the index, all sampling points were under "regular" conditions. 
Table V. Biological metrics and indices. For abbreviations, meanings and explanations about the variables, go to the methodology and to Table II.

\begin{tabular}{|c|c|c|c|c|c|c|c|c|c|}
\hline & JC1 & JC2 & JG1 & CA1 & CA2 & CA3 & PC1 & PC2 & PC3 \\
\hline Poly & 0.01 & 0.00 & 0.04 & 0.00 & 1.00 & 0.07 & 0.04 & 0.30 & 0.03 \\
\hline Tnt & 0.00 & 0.86 & 0.64 & 0.00 & 0.00 & 0.21 & 0.00 & 0.00 & 0.18 \\
\hline Lhof & 0.24 & 0.00 & 0.00 & 0.00 & 0.00 & 0.07 & 0.14 & 0.00 & 0.03 \\
\hline Dens & 1394 & 689 & 721 & 48 & 16 & 224 & 1234 & 737 & 529 \\
\hline S & 10 & 5 & 9 & 3 & 1 & 7 & 15 & 11 & 14 \\
\hline D & 0.34 & 0.55 & 0.41 & 0.33 & 1.00 & 0.21 & 0.29 & 0.17 & 0.14 \\
\hline TUB & 0.38 & 0.00 & 0.02 & 0.00 & 0.00 & 0.07 & 0.22 & 0.04 & 0.03 \\
\hline CHN & 0.06 & 1.00 & 0.84 & 0.00 & 1.00 & 0.86 & 0.65 & 0.46 & 0.64 \\
\hline TNP & 0.03 & 0.00 & 0.00 & 1.00 & 0.00 & 0.07 & 0.00 & 0.44 & 0.27 \\
\hline DSF & 0.52 & 1.00 & 0.84 & 1.00 & 1.00 & 0.85 & 0.65 & 0.46 & 0.64 \\
\hline SF & 5 & 1 & 5 & 1 & 1 & 3 & 5 & 5 & 5 \\
\hline HIS & 8.61 & 6.00 & 6.11 & 8.67 & 6.00 & 5.43 & 8.57 & 7.07 & 6.36 \\
\hline TOL & 0.91 & 0.00 & 0.09 & 0.67 & 0.00 & 0.21 & 0.73 & 0.54 & 0.52 \\
\hline TNTCHD & 0.00 & 0.88 & 0.76 & 0.00 & 0.00 & 0.67 & 0.02 & 0.24 & 0.62 \\
\hline CHD & 0.09 & 1.00 & 0.84 & 1.00 & 1.00 & 0.93 & 0.65 & 0.89 & 0.91 \\
\hline NAl & 0.39 & 0.00 & 0.09 & 0.00 & 0.00 & 0.07 & 0.35 & 0.04 & 0.03 \\
\hline FAM & 5 & 1 & 5 & 1 & 1 & 3 & 5 & 5 & 5 \\
\hline DF & 0.52 & 1.00 & 0.84 & 1.00 & 1.00 & 0.93 & 0.65 & 0.89 & 0.91 \\
\hline CF & 0.00 & 0.88 & 0.67 & 0.00 & 0.00 & 0.57 & 0.01 & 0.13 & 0.46 \\
\hline CG & 0.44 & 0.12 & 0.29 & 0.00 & 0.00 & 0.29 & 0.94 & 0.09 & 0.21 \\
\hline PRD & 0.55 & 0.00 & 0.00 & 1.00 & 0.00 & 0.07 & 0.00 & 0.48 & 0.30 \\
\hline SHR & 0.01 & 0.00 & 0.04 & 0.00 & 1.00 & 0.07 & 0.04 & 0.30 & 0.03 \\
\hline SCR & 0.00 & 0.00 & 0.00 & 0.00 & 0.00 & 0.00 & 0.01 & 0.00 & 0.00 \\
\hline FUNC & 3 & 2 & 3 & 1 & 1 & 4 & 4 & 4 & 4 \\
\hline D.FUNC & 0.50 & 0.80 & 0.53 & 1.00 & 1.00 & 0.42 & 0.88 & 0.35 & 0.34 \\
\hline ICB RES-SL & 3.00 & 3.25 & 2.75 & 3.00 & 3.25 & 2.75 & 3.25 & 2.50 & 2.50 \\
\hline & & & & & & & & & \\
\hline
\end{tabular}

\section{Environmental characterization and toxicity}

The bottom water from the reservoirs that was analyzed in this work presented a neutral $\mathrm{pH}$ $(6.88 \pm 0.52)$, satisfactory oxygenation $(8.99 \pm 1.54$ $\mathrm{mg} / \mathrm{L})$ and a warm temperature $\left(17.99 \pm 0.59^{\circ} \mathrm{C}\right)$. The Secchi disc readings were approximately $2.14 \pm 0.63 \mathrm{~m}$, and moderate electric conductivity was recorded $(35.55 \pm 5.34 \mu \mathrm{S} / \mathrm{cm})$.

The sediments were made up of more than $10 \%$ organic matter at JC1, CA1, PC1 and PC2. The organic matter at Paiva Castro was primarily coarse relative to that at JG-JC and CA. JC2, JC1 and CA2 were the sampling points with higher coarse inorganic sediments $(62.26 \pm 0.59 \%)$. The Paiva Castro inorganic sediment was primarily formed by fine particles $(82.55 \pm 8.31 \%)$.

Principal component 1 (ENV) explained 62.63\% (PCA1 broken stick $=34.73 \%$ ) and could be used to distinguish among the three reservoirs. An increase in the ENV occurred when the COM and FIS decreased and when the $\mathrm{CIS}$ and $\mathrm{pH}$ increased (Figure 3). 
The metals Al, As, Cd, Cu and $\mathrm{Cr}$ had a TU $\geq 1$ in one or more sediment samples. In addition, $\mathrm{Al}$, $\mathrm{Cr}$ and $\mathrm{Cu}$ had a TU $\geq 1$ in the bottom water. The As, $\mathrm{Cd}, \mathrm{Ni}$ and $\mathrm{Pb}$ concentrations in the water could not be determined once they fell below the limit of quantification (Table VI).

Correlations were observed between the metal toxicity in the sediments and some other environmental variables, with $\mathrm{As}$ and $\mathrm{Al}$ in relation to FOM ( $r=0.80$ and 0.88 ), $\mathrm{Cu}$ and $\mathrm{Cd}$ with COM (0.83 and 0.91), CU_s with FIS and CIS (0.66 and -0.71) and Cr with FIS (-0.69) and CIS (0.65).

A correlation between metal toxicities in sediments was observed between As-Cu (0.72), As-Cd (0.75) and As-Al (0.84). As a consequence, data about As toxicity were not considered in the models (it had a lower toxicity than $\mathrm{Cu}$ ). Because $\mathrm{Cd}$ was toxic in only one sample, it was not considered either. With regards to the water analysis, only Al had a TU $\geq 1$ in more than one sample, and it was not correlated with any other variable.

\section{Biological and environmental interactions and the linear mixed effects models}

By comparing trophic state data with biological variables, it could be concluded that the trophic conditions did not influence the BMI metrics and indices in our research (Table VII). Some biological variables were correlated. In such cases, the simplest one was maintained, and the correlated variable removed to avoid double weight in the biotic PCA. Dominance (correlated with Polypedilum sp. and species richness); DF (correlated with CHD, NAI and FAM); SF (correlated with TNP); Hilsenhoff index (correlated with TOL and TNT: CHD); and D.FUNC (correlated with FUNC) were previously removed and did not entered to the biotic PCA analyses.

The PCA-based variables can be broadly described as follows (Figure 4):
- Species/Genus level: low values indicate the predominance of $L$. hoffmeisteri while high values point to higher abundances of Tanytarsus spp.

- Subfamily level: low values were weakly associated with higher number of subfamilies while higher values were indicative of higher abundances of Chironominae (weakly) and Tubificinae (strong relation).

- Family level: low values were weakly associated with high number of families while high values were strongly associated with higher abundances of Chironomidae and Naididae.

Function level: higher values were indicative of higher abundance of collector-gatherers.

- Tolerance level: higher values were weakly associated with higher abundance of organisms considered as "tolerant" and strongly associated with higher TNT: CHD rates.

- Abundance: PC1 values were related to lower density $\left(\log _{2}\right)$ values.

In considering all of the selected models, the most frequent abiotic variables were the toxicity of aluminum in the water (Al_w) and the toxicity if chromium (Cr_s) in sediments (importance $\geq$ 0.50). The neutral environmental gradient and other metal toxicities could not be considered as good predictors of the biological data. The biological variable "tolerance" did not respond to any group of abiotic factors considered in this research. The strongest model was that described by "subfamily" variable (2417.53 times stronger then the reduced model).

\section{DISCUSSION}

\section{Environmental characterization and toxicity}

The sediment grain size, organic matter content and $\mathrm{pH}$ were relevant to the $\mathrm{BMI}$ assemblages, and they presented a well-established gradient along the reservoirs. Previous studies indicated the relevance of some of these environmental 

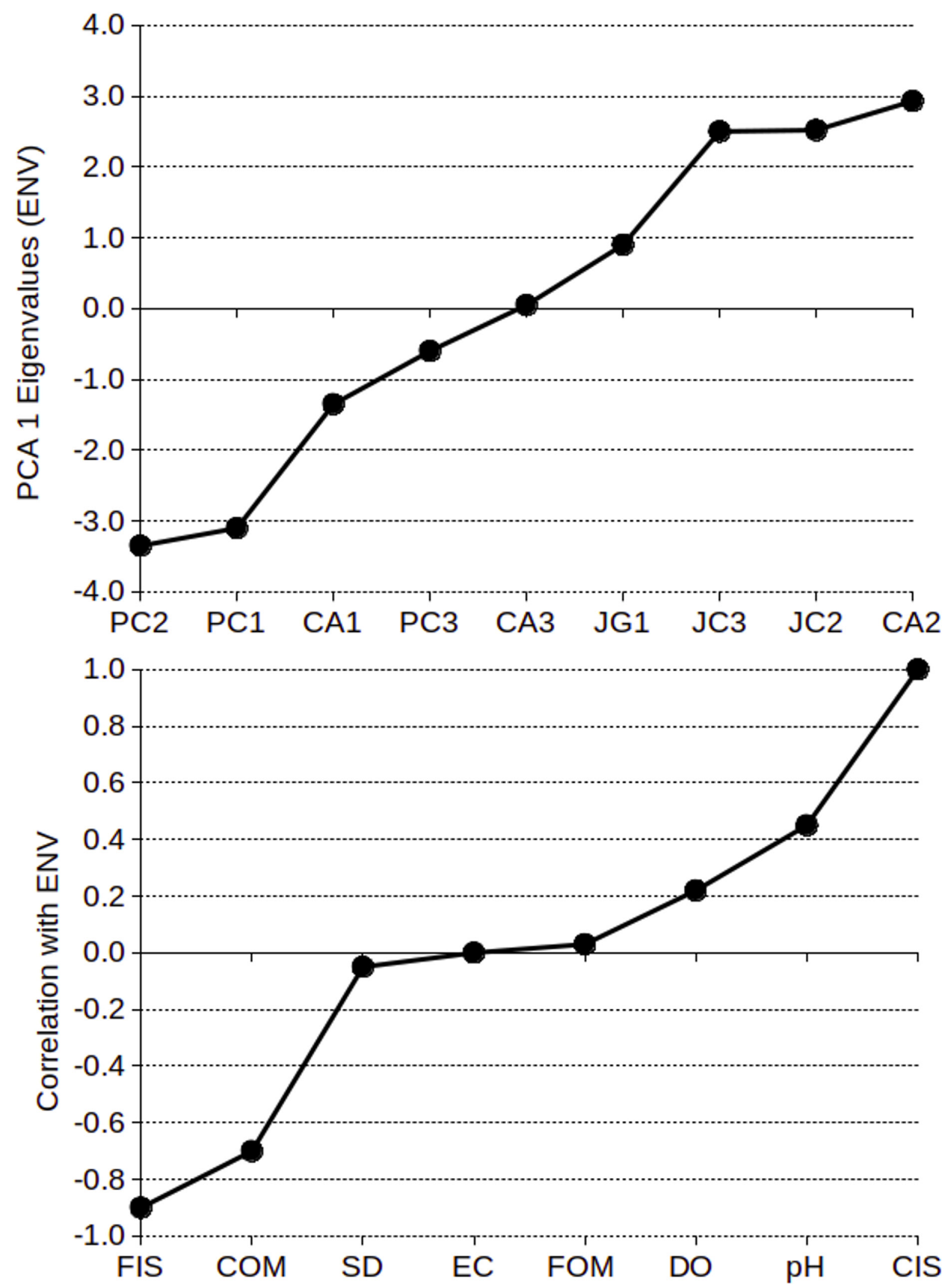

Figure 3. PCA1 results: PCA1 eigenvalues of sampling points and Pearson's correlation values between environmental neutral variables and PCA1 (ENV) in view of the fine and coarse inorganic particle proportions in the sediments (FIS and CIS), the proportion of coarse and fine organic matter (FOM and COM) in the sediments, in addition to the $\mathrm{pH}$, dissolved oxygen (DO), transparency (SD) and electric conductance (EC) of the water. The following reservoirs belonging to the Cantareira Complex, SP, Brazil, were considered: Jaguari (JG)-Jacarei (JC), Cachoeira (CA) and Paiva Castro (PC). 
Table VI. Potential toxicity.

\begin{tabular}{|c|c|c|c|c|c|c|c|c|c|}
\hline & & Al & As & $\mathrm{Cd}$ & $\mathrm{Cr}$ & $\mathrm{Cu}$ & $\mathrm{Ni}$ & $\mathbf{P b}$ & $\mathrm{Zn}$ \\
\hline \multirow{10}{*}{ 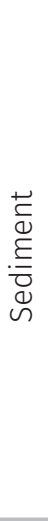 } & $\mathrm{JC1}$ & 5.4 & 1.4 & 0.1 & 1.5 & 1.0 & 0.8 & 0.7 & 0.8 \\
\hline & $\mathrm{JC2}$ & 3.8 & 0.9 & 0.1 & 2.6 & 0.8 & 0.9 & 0.4 & 0.4 \\
\hline & $J G 1$ & 4.4 & 1.1 & 0.5 & 1.7 & 0.7 & 0.8 & 0.5 & 0.7 \\
\hline & CA1 & 5.0 & 1.4 & $<\mathrm{LQ}$ & 1.8 & 1.6 & 1.2 & 0.7 & 0.7 \\
\hline & CA2 & 2.2 & 0.7 & $<\mathrm{LQ}$ & 1.5 & 0.6 & 0.6 & 0.2 & 0.4 \\
\hline & CA3 & 1.9 & 0.7 & $<\mathrm{LQ}$ & 1.2 & 0.8 & 0.7 & 0.3 & 0.3 \\
\hline & PC1 & 1.3 & 0.9 & 0.1 & 0.7 & 1.3 & 0.5 & 0.4 & 0.5 \\
\hline & PC2 & 4.2 & 1.6 & 1.1 & 1.2 & 2.6 & 0.9 & 1.0 & 0.8 \\
\hline & PC3 & 1.1 & 0.5 & 0.3 & 0.9 & 0.9 & 0.5 & 0.5 & 0.3 \\
\hline & LQ & 0.001 & 0.052 & 0.003 & 0.002 & 0.003 & 0.012 & 0.023 & 0.005 \\
\hline \multirow{10}{*}{ 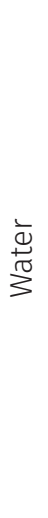 } & $\mathrm{JC1}$ & 177.4 & $<\mathrm{LQ}$ & $<\mathrm{LQ}$ & 1.1 & 2.9 & $<\mathrm{LQ}$ & $<\mathrm{LQ}$ & 0.8 \\
\hline & $\mathrm{JC2}$ & 39.4 & $<\mathrm{LQ}$ & $<\mathrm{LQ}$ & 0.5 & $<\mathrm{LQ}$ & $<\mathrm{LQ}$ & $<\mathrm{LQ}$ & 0.1 \\
\hline & JG1 & 13.1 & $<\mathrm{LQ}$ & $<\mathrm{LQ}$ & 0.3 & $<\mathrm{LQ}$ & $<\mathrm{LQ}$ & $<\mathrm{LQ}$ & 0.2 \\
\hline & CA1 & 18.3 & $<\mathrm{LQ}$ & $<\mathrm{LQ}$ & 0.3 & $<\mathrm{LQ}$ & $<\mathrm{LQ}$ & $<\mathrm{LQ}$ & 0.5 \\
\hline & CA2 & 1.6 & $<\mathrm{LQ}$ & $<\mathrm{LQ}$ & 0.1 & $<\mathrm{LQ}$ & $<\mathrm{LQ}$ & $<\mathrm{LQ}$ & 0.3 \\
\hline & CA3 & 38.2 & $<\mathrm{LQ}$ & $<\mathrm{LQ}$ & 0.6 & $<\mathrm{LQ}$ & $<\mathrm{LQ}$ & $<\mathrm{LQ}$ & 0.4 \\
\hline & PC1 & 7.2 & $<\mathrm{LQ}$ & $<\mathrm{LQ}$ & 0.1 & $<\mathrm{LQ}$ & $<\mathrm{LQ}$ & $<\mathrm{LQ}$ & 0.2 \\
\hline & PC2 & 5.5 & $<\mathrm{LQ}$ & $<\mathrm{LQ}$ & 0.1 & $<\mathrm{LQ}$ & $<\mathrm{LQ}$ & $<\mathrm{LQ}$ & 0.4 \\
\hline & PC3 & 2.4 & $<\mathrm{LQ}$ & $<\mathrm{LQ}$ & $<\mathrm{LQ}$ & $<\mathrm{LQ}$ & $<\mathrm{LQ}$ & $<\mathrm{LQ}$ & 0.0 \\
\hline & LQ & 0.001 & 0.039 & 0.002 & 0.001 & 0.001 & 0.006 & 0.025 & 0.001 \\
\hline
\end{tabular}

* Values expressed in toxic units, of metals in the bottom water and sediments from the Jaguari (JG), Jacareí, Jacareí (JC), Cachoeira (CA) and Paiva Castro (PC) reservoirs in the Cantareira Complex, SP, Brazil. A TU $\geq 1$ indicates toxicity. The limits of quantification (LQ) are expressed in $\mathrm{mg} / \mathrm{Kg}$ for sediment samples and in $\mathrm{mg} / \mathrm{L}$ for water.

variables to the composition and distribution of BMI (Beghelli et al. 2012, Jones et al. 2012).

In addition, changes in these environmental variables tend to alter the distribution of the metals in the environment, as well as their bioavailability (Fan et al. 2014, He et al. 2012, Rangel et al. 2011). The correlations obtained in the present study corroborate this assumption, indicating the interrelations between the sediment composition (the predominant grain size and coarse organic matter proportions) and metal concentrations in sediments. The proportion of COM, CIS and FIS in sediments may be related to the integrity of the riparian forest, which has an important role in the sediment composition from falling debris and acts as a barrier to the movement of particles from land to water (Naiman \& Décamps 1997).

In considering the sediment toxicity, the following two primary groups could be distinguished: a low toxicity group formed by PC1, PC3, CA2 and CA3 and a high toxicity group that includes Jaguari-Jacareí sampling points, PC2 and CA1. Despite the fact that PC2 could be grouped with JC-JG and CA1 in relation to general toxicity, it must be qualitatively distinguished. The toxicity of PC2 is related to $\mathrm{Cu}_{-} \mathrm{S}$ and $\mathrm{Cd} \_\mathrm{s}$, and the primary contaminants in JC-JG and CA1 are $\mathrm{Al}$ and $\mathrm{Cr}$.

The water toxicity was primarily determined by the Al, which was present in higher concentrations than the established TRV in all of 
PC 1 Species $(50.88 \%)$

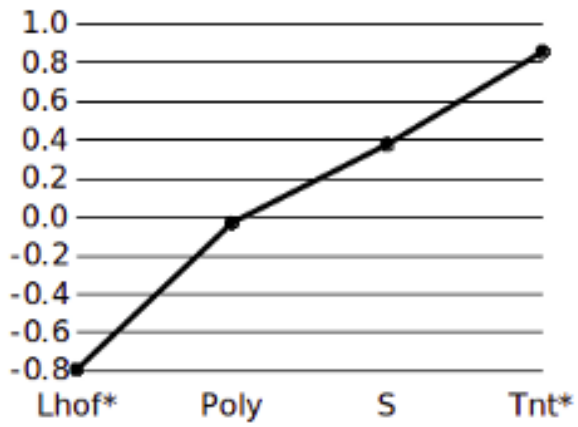

PC 1 Family (91.84\%)

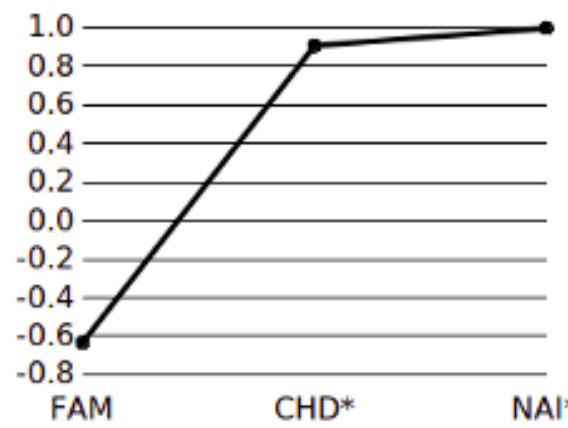

PC 1 Tolerance $(96.41 \%)$
PC 1 Subfamily (75.73\%)

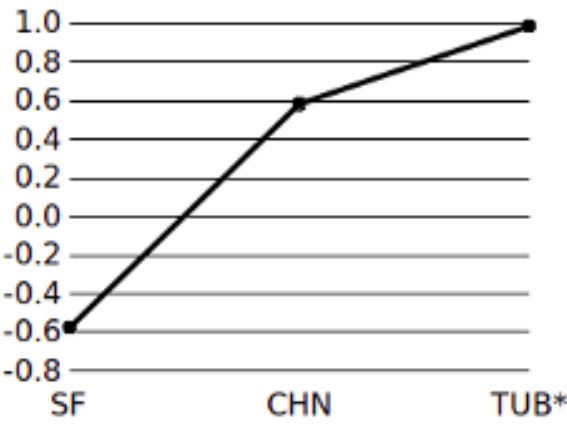

PC 1 Function (59.25\%)

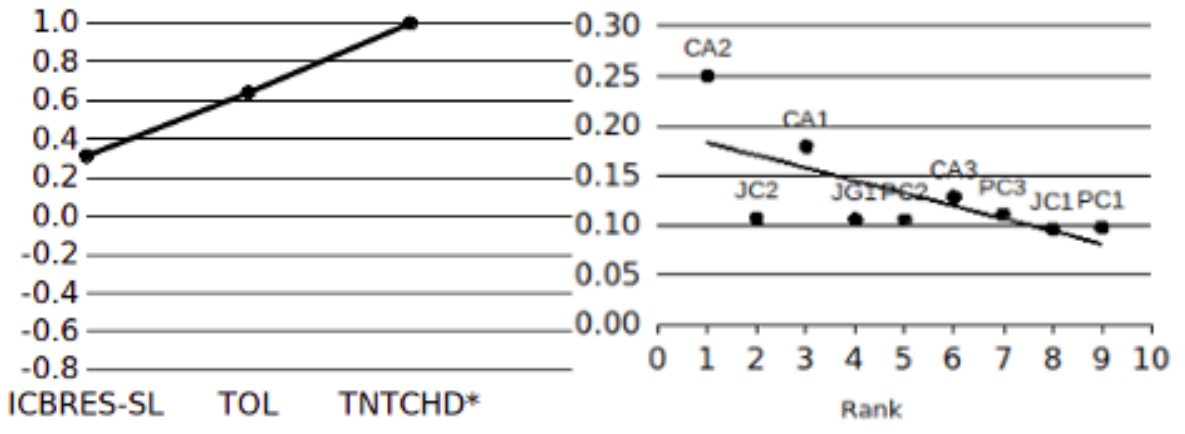

Figure 4. Biotic PC1 eigenvalues considering each biological level of variables (species/genus; subfamily; family; tolerance; function). Density values was considered separately because it comprises a level with an unique variable.

* the asterisks indicate the variables with higher correlation with PCA1 in each category $\left(\mathrm{R}^{2}>0.7\right)$

the samples. Despite a well-documented effect of acidity on Al toxicity related to its low solubility when in neutral conditions, many works with benthic macroinvertebrates demonstrated that even in such cases aluminium is still bioavailable to BMI (Michahilova et al. 2003, Shuhaimi-Othman et al. 2011, 2012).
The toxicity from aluminum in the water varied from 1.6 in CA2 (0.139 mg/L) to $177.4 \mathrm{TU}$ in JC1 $(15.433 \mathrm{mg} / \mathrm{L})$, indicating values that were many times greater than the LEL or ERL for test organisms as established by the US-EPA 1999. The highest values were concentrated upstream where there is a lower proportion of natural 
forests (Whately \& Cunha 2007) and a proximity to a traffic-intensive road that promoted industrialization (Oliveira et al. 2008). Both the road (Bhattacharya et al. 2013) and the industrial park (Johnson et al. 2006) may have favored the pollution of the headwater reservoirs with $\mathrm{Cr}$ and Al.

The specific situation of the PC2 sampling point must be related to the water flow, macrophytes and riparian forest and also to human impacts. This sampling point is in a backwater area where the presence of macrophytes and a denser riparian forest could be observed. This situation favors the reduction of water flow and sedimentation, promoting metal and organic matter accumulation (Martins et al. 2015). The positive correlation of $\mathrm{Cu}$ and $\mathrm{Cd}$ with COM and $\mathrm{Cu}$ with FIS are indicative of the tendencies of these metals to adsorb to these sediment fractions, which were especially high in Paiva Castro (Demirak et al. 2012, Martins et al. 2015). Despite having the highest proportion of natural vegetation, this area also has the highest proportion of urbanized areas, and pollution by multiple metals is common in such cases (Zhang \& Liu 2014).

\section{Biological responses}

It is necessary to mention here that seasonality effects were not considered in the present work. Instead, we optioned to replicate sampling design during the same season to avoid an extra source of variability. Effects of seasonality in benthic macroinvertebrates composition, are usually associated with changes in organic matter, dissolved oxygen or in trophic state conditions. These variables were monitored here (Linares et al. 2013, Beghelli et al. 2014).

Given the complex differences the reason to avoid seasonality effects is similar to those that drives laboratorial assays: we lose some environmental information to get results that are more precise by controlling environmental variability.

Considering that the aim of this research was to get effects of toxicity by metals on BMI by generating conceptual models of type doseresponse, the results and conclusions here are not expected to be significantly affected by seasonality.

T-tests on the trophic state showed that the trophic conditions were not affecting the biological variables studied here. As mentioned, many works have already presented some of the metrics and indices considered in this research (the TOL, HIS, the proportion of Limnodrilus or tubificids, species richness, and dominance) to eutrophication or a "general" environmental condition (Beghelli et al. 2014, Qin et al. 2014). This result is likely more a consequence of low variations in the trophic state among sampling points than the true absence of a relation.

Furthermore, in abroad sense, eutrophication is made up of other changes that are more directly related to $\mathrm{BMI}$ assemblages than the surface TP, TN or chlorophyll-a concentrations because increasing the organic matter in sediments depletes the dissolved oxygen on the bottom, in addition to $\mathrm{pH}$ alterations and the death of macrophytes (Takamura et al. 2009, Nelson and Steinman 2013, Qin et al. 2013). The first three factors were considered in the neutral environmental gradient (ENV). The BMI assemblages responded to metal toxicity in water from $\mathrm{Al}$ and in sediments from $\mathrm{Al}, \mathrm{Cr}$ and Cu. Moreover, the ENV variable consisting of the COM, FIS, CIS and $\mathrm{pH}$ was relevant and helped to explain seven of the 25 biological variables.

Novelties and differences between the present work and other similar studies should be highlighted. Zhang \& Liu 2014 performed a comprehensive study on BMI assemblages and periphyton responses to the environment. Other authors used an ecological risk approach to 
study human impacts on three distinct habitat types. These authors related the correlation of BMI metrics to the ecological risk index for metals in distinct areas. In comparison with the present research, the previous study has the advantage of being more comprehensive by including many stressing conditions in addition to two distinct biotic assemblages. However, our research presents some advances in the sense that the present study is more specific. First, the work of Zhang \& Liu (2014) presented many sources of variation such as seasonality and organic pollution, and furthermore, their pattern of environmental conditions (toxicity from distinct metallic elements presented the same pattern) and their statistical approach would not permit the differentiation of specific metal effects against other environmental variables.

The present work highlighted more specific interactions by considering the toxicity of distinct elements in sediments and water in addition to the random effects of reservoirs and other relevant environmental characteristics in the ENV component. Furthermore, the toxicity caused by individual metals in the Cantareira Complex did not present similar patterns to one another, and thus, the toxicity from Al_w, Al_s, $\mathrm{Cu}$ _s and $\mathrm{Cr}$ s could be clearly differentiated. The trophic state did not play an important role in our biological data.

The biological variables that were analyzed in this work were based on proportions and not on direct abundance, with the exception of the density and taxa numbers. Under these considerations, it can be assumed that any positive relation between a specific taxonomic or functional group and metal toxicity is not the consequence of a benefit that was directly caused by toxicity on the biological variable. Instead, it is much more plausible that it is a consequence of a proportional reduction in other more sensitive groups ((Mackintosh et al. 2015, Milner et al. 2016).

Only Al_w and Cr_s could be considered as good predictor variables to BMI assemblage composition and distribution. Variations among taxonomic and functional indexes and metrics could be attributed to variations in sensitivity to specific metals considering characteristics such as escape strategies, physiological mechanisms of toxicity avoidance, the degree of exposition to sediments or water and feeding habits (MéndezFernández et al. 2013, Clements et al. 2015, He et al. 2015).

Environments with high $\mathrm{Cr}_{-}$s and low Al_w concentrations could be associated to predominance of Chironomidae and Naididae when considering the family level and Chironominae and Tubificinae (subfamily level). When species/genus level is achieved, we predict high relative abundances of Tanytarsus sp. (Chironominae) in chromium rich sediments (low Al_w) and high relative abundances of $L$. hoffmeisteri (Tubificinae) in environments with high Al_w values (low Cr_s). It is important to notice that only the finest taxonomic resolution level could detect this difference among chironomids and oligochaetes.

The results of ecotoxicological assays addressed aluminum in water (ShuhaimiOthman et al. 2011, 2012) and chromium in sediments (Flores-Tena \& Martínez-Tabche 2001, Campagna et al. 2013). These results corroborated our data on the Limnodrilus sp. and Tanytarsus sp. responses to these metals. A higher sensitivity to aluminum in water was observed in Chironomidae larvae (Chironomus javanus, $\mathrm{LC}_{50} 96 \mathrm{~h}=0.17 \mathrm{mg} / \mathrm{L}$ ) in comparison with a Naididae worm (Nais elinguis, $\mathrm{LC}_{50} 96 \mathrm{~h}$ $=3.87 \mathrm{mg} / \mathrm{L}$ ). The opposite was observed for sediments that were spiked with chromium (Chironomus xanthus, $\mathrm{LC}_{50} 96 \mathrm{~h}=340.96 \mathrm{mg} / \mathrm{Kg}$; L. hoffmeisteri, $\mathrm{LC}_{50} 96 \mathrm{~h}=5.11 \mathrm{mg} / \mathrm{Kg}$ ). 
As we expected, tolerance indices were not good predictors to metal pollution in our study. The main explanation for that must be the relation of such classification of "tolerance" based on organic pollution, eutrophication or deforestation. In environments where toxicity is not associated to organic pollution or eutrophication, these indices may vary in a different way. Similar results were observed by López-Dovál et al. 2012, who tested the response of an index on the basis of general pollution tolerance that was similar to that of HIS against the TU for chemicals, especially metals, in four Spanish basins. The authors did not find significant correlations between the variables.

Despite to has some power of prediction, the functional feeding guilds were the weaker model obtained been just 2.71 times more probable than the reduced. Composition in terms of food intake are related essentially to the entrance of organic matter from the surroundings and to the water flow. The relation of such kind of biological traits to metal pollution must be consequence of metal binding to organic matter and sediments instead toxicity.

Our model suggests the occurrence of an assemblage dominated by collector-gatherers as the concentration of chromium in sediments increases. Considering that toxicity by $\mathrm{Cr}$ _s was higher in reservoir with less natural vegetation some care must be used to interpret this model. Environments with higher proportion of riparian forest are expected to shelter higher diversity of feeding groups than environments with other land uses (Cummins et al. 2005, Compin \& Céréghino 2007).

In fact, ecotoxicological assays have demonstrated toxic effects of Al_w on BMI organisms even at neutral pH. Results reported by Shuhaimi-Othman et al. 2011, 2012 are representative of the two predominant families and subfamilies recorded in this work.
Concentrations higher than $\mathrm{LC}_{50}$ reported for C. javanus (Shuhaimi-Othman et al. 2011) were recorded in four cases (JC1, JC2, CA1 and CA3) while an Al_w concentration higher than the $\mathrm{LC}_{50}$ value reported for $N$. elegans were recorded in sample from JC1.

Density decreased as toxicity by aluminium in water grew. Considering the broad depressor effect of toxicity on biota and that Al_w was the toxicant with highest values in terms of TU, this result reinforces the idea that assemblage abundance measures can be suitable to assess the most severe impacts related to toxicity in a specific environment.

The taxonomic approach was clearly the group with the best predictors to metal pollution in Cantareira Complex. The models obtained here follow a gradient of strength: family < species / genus < subfamily taxonomic level. Despite many debates about the ideal taxonomic resolution for bioassessment purposes, researchers usually agree that the choice of the best resolution must consider some compromise among scientific ideal, bioassessment purposes, financial and logistic realities (Jones 2008, Buss \& Vitorino 2010, Frizzera \& Alves 2012). Our results show that subfamily level of resolution was the most adequate to monitoring toxic effects of metals in Cantareira Complex with the lower loss of truly valid information to predict toxicity.

It means that when taxonomic resolution was limited to family level, many information was lost (the model was 76.75 times weaker) in comparison to subfamily level. However, when comparing the subfamily level with the finest resolution, the subfamily could be considered as the most adequate and parsimonious choice.

In considering our results and those in the literature, we strongly recommend the development of specific tolerance indices for metal pollution in future studies on BMI assemblages. In this respect, the present work 
provided important data by demonstrating a set of indices and metrics that truly respond to metal toxicity as also compared distinct taxonomic resolutions. One advance made by this work was that the trophic state did not present significant effects, and other environmental components that were frequently relevant to BMI assemblages were analyzed in the models to assess the effects that were caused separately by metals.

The elaboration of a general toxicity index may present some problems related to the differential sensibilities of organisms to specific toxicants. Indices based on total tolerance scores may fail exactly because of these specific differences. For instance, L. hoffmeisteri is generally considered as "tolerant", but it is more sensitive to chromium contamination in sediments than Tanytarsus sp. which is usually considered as a "sensitive" organism.

\section{CONCLUSIONS}

The present work showed the effects of metal toxicity (potential risk) in water and sediments on BMI assemblages. The biological variables responded to the toxicity at different levels (coarse taxonomic resolution, fine taxonomic resolution, functional indices and density).

From our results, we concluded that: the variables from the taxonomic group were better bioindicators. Subfamily taxonomic resolution was the most adequate to predict metal toxicity. The functional feeding group responses to metal toxicities may be related to metal adsorption and complexation with organic matter and sediment grains as also to the food ingestion and mobility of organisms.

With our findings, we provided the basis to develop a new BMI index for metal pollution in oligotrophic reservoirs in tropical environments. Further studies may apply similar approaches in eutrophic reservoirs. The application of these
Table VII. T-test with trophic state results ( $p$ values).

\begin{tabular}{|c|c|c|c|}
\hline & TP & CL & IET \\
\hline Poly & 0.75 & 0.51 & 0.96 \\
\hline Tnt & 0.77 & 0.99 & 0.42 \\
\hline Lhof & 0.20 & 0.03 & 0.72 \\
\hline$S$ & 0.59 & 0.86 & 0.97 \\
\hline$D$ & 0.27 & 1.00 & 0.58 \\
\hline TUB & 0.20 & 0.02 & 0.62 \\
\hline $\mathrm{CHN}$ & 0.83 & 0.22 & 0.99 \\
\hline TNP & 0.31 & 0.54 & 0.38 \\
\hline DSF & 0.94 & 0.39 & 0.93 \\
\hline SF & 0.67 & 0.63 & 0.41 \\
\hline $\mathrm{CHD}$ & 0.12 & 0.00 & 0.30 \\
\hline NAI & 0.42 & 0.09 & 0.60 \\
\hline FAM & 0.67 & 0.63 & 0.41 \\
\hline DF & 0.38 & 0.05 & 0.40 \\
\hline HIS & 0.82 & 0.31 & 0.86 \\
\hline TOL & 0.90 & 0.26 & 0.76 \\
\hline TNTCHD & 0.78 & 0.65 & 0.68 \\
\hline CF & 0.94 & 0.75 & 0.68 \\
\hline$C G$ & 0.85 & 0.70 & 0.99 \\
\hline PRD & 0.96 & 0.54 & 0.75 \\
\hline SHR & 0.75 & 0.51 & 0.96 \\
\hline SCR & 0.49 & 0.62 & 0.43 \\
\hline FUNC & 0.41 & 0.89 & 0.76 \\
\hline D.FUNC & 0.85 & 0.67 & 0.66 \\
\hline DENS & 0.36 & 0.08 & 0.49 \\
\hline
\end{tabular}

metrics to oligotrophic reservoirs without metal toxicity is also desirable to obtain real reference conditions. 
Table VIII. Model selection results.

\begin{tabular}{|c|c|c|c|c|c|c|c|c|c|}
\hline DV & Intercept & ENV & Al_S & Cr_s & Cu_s & Al_w & $w$ & $w_{0}$ & $w / w_{0}$ \\
\hline $\begin{array}{c}\text { Species/ } \\
\text { Genus }\end{array}$ & 5.68 & $---(0.33)$ & $---(0.35)$ & $\begin{array}{c}-4.739 \\
(0.96)\end{array}$ & $---(0.43)$ & $0.0357(0.96)$ & 1 & 0.0042 & 243.47 \\
\hline Subfamily & -2.743 & $---(0.43)$ & $---(0.40)$ & $\begin{array}{c}2.983 \\
(0.95)\end{array}$ & $---(0.38)$ & $-0.0471(0.38)$ & 1 & 0.0004 & 2417.53 \\
\hline Family & -3.875 & $---(0.45)$ & $---(0.42)$ & $\begin{array}{c}3.722 \\
(0.81)\end{array}$ & $---(0.42)$ & $-0.0454(0.82)$ & 1 & 0.0317 & 31.50 \\
\hline Tolerance & 0.00005 & $---(0.35)$ & $---(0.38)$ & $---(0.48)$ & $---(0.44)$ & $---(0.36)$ & 1 & 1.0000 & 1.00 \\
\hline Function & -17.46 & $---(0.47)$ & $---(0.40)$ & $\begin{array}{c}12.02 \\
(0.64)\end{array}$ & $---(0.43)$ & $---(0.42)$ & 1 & 0.3697 & 2.71 \\
\hline Abundance & -1.121 & $---(0.46)$ & $---(0.34)$ & $---(0.46)$ & $---(0.34)$ & $-0.033(0.76)$ & 1 & 0.1653 & 6.05 \\
\hline
\end{tabular}

*For relations between the BMI assemblage metrics and indices and the potential toxicity (TU) of metals or the neutral environmental gradient (ENV). Parameters (intercepts and coefficients) of variables with (values in parenthesis) are shown. The probability of the selected model $(w)$, of the reduced model $\left(w_{0}\right)$ and the number of times the selected model was more parsimonious then the reduced model $\left(w / w_{0}\right)$. Values in bold indicate that a model that was strong enough to predict the biological variable could not be formulated.

\section{Acknowledgments}

The authors thank the Fundação de Amparo à Pesquisa do Estado de São Paulo (FAPESP process numbers 2012/11890-4, 2012/16420-6, 2013/03494-4, 2013/08272-0 and 2014/22581-8) for its financial support.

\section{REFERENCES}

ALVES RIS, SAMPAIO CF, NADAL M, SCHUHMACHER M, DOMINGO JL \& SEGURA-MUÑOZ SI. 2014. Metal concentrations in surface water and sediments from Pardo River, Brazil: Human health risks. Environ Res 133: 149-155.

AZEVÊDO DJS, BARBOSA JEL, GOMES WIA, PORTO DE, MARQUES IC \& MOLOZZI J.2015. Diversity measures in macroinvertebrate and zooplankton communities related to the trophic status of subtropical reservoirs: Contradictory or complementary responses? Ecol Ind 50: 135-149.

BAPTISTA DF. 2008. Uso de macroinvertebrados em procedimentos de biomonitoramento em ecossistemas aquáticos. Oecol Bras 12: 425-441.

BAPTISTA DF, BUSS DF, EGLER M, GIOVANELLI A, SILVEIRA MP \& NESSIMIAN JL 2007. A multimetric index based on benthic macroinvertebrates for evaluation of Atlantic Forest streams at Rio de Janeiro State, Brazil. Hydrobiologia 575: 83-94.

BAPTISTA DF, HENRIQUES-OLIVEIRA AF, OLIVEIRA RBS, MUGNAI R, NESSIMIAN JL \& BUSS DF. 2013. Development of a benthic multimetric index for the Serra da Bocaina bioregion in Southeast Brazil. Braz J Biol 73: 573-583.
BAPTISTA DF, SOUSA RSG, VIEIRA CA, MUGNAI R, SOUZA AS \& OLIVEIRA RBS. 2011. Multimetric index for assessing ecological condition of running waters in the upper reaches of the Piabanha-Paquequer-Preto Basin, Rio de Janeiro, Brazil. Zoologia 28: 619-628.

BEGHELLI FGS, SANTOS ACA, URSO-GUIMARÃES MV \& CALIJURI MC. 2012. Relationship between space distribution of the benthic macroinvertebrates community and trophic state in a Neotropical reservoir (Itupararanga, Brazil). Biota Neotrop 12: 114-124.

BEGHELLI FGS, SANTOS ACA, URSO-GUIMARÃES MV \& CALIJURI MC. 2014. Spatial and temporal heterogeneity in a subtropical reservoir and their effects over the benthic macroinvertebrate community. Acta Limnol Bras 26: 306-317.

BETTINETTI R, PONTI B, MARZIALI L \& ROSSARO B. 2012. Biomonitoring of lake sediments using benthic macroinvertebrates. TrAC 36: 92-102.

BHATTACHARYA T, CHAKRABORTY S, TUTEJA D \& PATEL M. 2013. Zinc and Chromium Load in Road Dust, Suspended Particulate Matter and Foliar Dust Deposits of Anand City, Gujarat. Open J Met 3: 42-50.

BIN H, YUN ZJ, SHI JB \& JIANG GB. 2013. Research progress of heavy metal pollution in China: Sources, analytical methods, status, and toxicity. Chinese Sci Bull 58: 134-140.

BONADA N, PRAT N, RESH VH \& STAZNER B. 2006. Developments in aquatic insect biomonitoring: A comparative analysis of recent approaches. Annu Rev Entomol 51: 495-523. 
BORKENTA\&SPINELLIGR.2007. Neotropical Ceratopogonidae (Diptera: Insecta). In: Adis J et al. Aquatic biodiversity in Latin America, v. 4. Bulgaria: Pensoft Publishers, 199 p.

BRAND C \& MISERENDINO ML. 2015. Testing the performance of macroinvertebrate metrics as indicators of changes in biodiversity after pasture conversion in Patagonian mountain streams. Water, Air Soil Poll 226: 370-387.

BRINKHURST RO \& MARCHESE M. 1992. Guía para la identificación de Oligoquetos acuáticos continentales de Sud y Centroamérica. Asoc. Cienc. Nat. Litoral. Colección Climax № 6: Segunda Edición, 207 p.

BURNHAM KP, ANDERSON DR \& HUYVAERT KP. 2011. AIC model selection and multimodel inference in behavioral ecology: some background, observations, and comparisons. Behav Ecol Sociobiol 65: 23-35.

BUSS DF \& VITORINO AS. 2010. Rapid bioassessment protocols using benthic macroinvertebrates in Brasil: evaluation of taxonomic sufficiency. I N Amer Benthol Soc 29: 562-571.

CAMPAGNA AF, RODRIGUES BK, NOGUEIROL RC, VERANI NF, ESPINDOLA ELG \& ALLEONI LRF. 2013. Use of artificial sediment to assess toxicity of chromium on Chironomus xanthus, Danio rerio and Poecilia reticulate. Acta Limnol Bras 25: 42-53.

CARLSON RE. 1977. A trophic state index for lakes. Limnol Ocean 22: 361-369.

CARVALHO EM \& UIEDA VS. 2009. Diet of invertebrates sampled in leaf-bags incubated in a tropical headwater stream. Zoologia (Curitiba) 26: 694-704.

CASTRO-CATALÀ N ET AL. 2015. Ecotoxicity of sediments in rivers: Invertebrate community, toxicity bioassays and the toxic unit approach as complementary assessment tools. Sci Total Environ 540 297-306.

CETESB - COMPANHIA AMBIENTAL DO ESTADO DE SÃO PAULO. 2003. Macrofauna bentônica de água doce: Avanços metodológicos III. 74 p. Disponível em: <http:// aguasinteriores.cetesb.sp.gov.br/wp-content/uploads/ sites/32/2013/11/05.zip> Acessado em dez/2015.

CETESB - COMPANHIA AMBIENTAL DO ESTADO DE SÃO PAULO. 2012. Protocolo para biomonitoramento com as comunidades bentônicas de rios e reservatórios do Estado de São Paulo. 115p. Disponível em: <http:// aguasinteriores.cetesb.sp.gov.br/wp-content/uploads/ sites/32/2013/11/protocolo-biomonitoramento-2012. pdf $>$ Acessado em dez/2015.

CETESB - COMPANHIA AMBIENTAL DO ESTADO DE SÃO PAULO. 2015. Qualidade das águas superficiais no estado de São Paulo. 2014. Disponível em: <http://aguasinteriores. cetesb.sp.gov.br/wp-content/uploads/sites/32/2013/11/ agua-doce-parte1-corrigido.pdf.> Acessado em nov/2015.

CLEMENTS WH, KASHIAN DR, KIFFNEY PM \& ZUELLIG RE. 2015. Perspectives on the context-dependency of stream community responses to contaminants. Freshwat Biol 61: 1991-2220.

CLEWS E, LOW E, BELLE CC, TODD PA, EIKAAS HS \& NG PKL. 2014. A pilot macroinvertebrate index of the water quality of Singapore's reservoirs. Ecol Indic 38: 90-103.

COLAS F, VIGNERON A, FELTEN V \& DEVIN S. 2014. The contribution of a niche-based approach to ecological risk assessment: Using macroinvertebrate species under multiple stressors. Environ Pollut 185: 24-34.

COMPIN A \& CÉRÉGHINO R. 2007. Spatial patterns of macroinvertebrate functional feeding groups in streams in relation to physical variables and land-cover in Southwestern France. Landscape Ecology 22: 1215-1225.

COUCEIRO SRM, HAMADA N, FORSBERG BR, PIMENTEL TP \& LUIZ SLB. 2012. A macroinvertebrate multimetric index to evaluate the biological condition of streams in the Central Amazon region of Brazil. Ecol Ind 18: 118-125.

CUMMINS KW \& KLUG MJ. 1979. Feeding Ecology of stream invertebrates. An Review Ecol Syst 10: 147-172.

CUMMINS KW, MERRIT RW \& ANDRADE PCN. 2005. The use of invertebrate functional groups to characterize functional groups in selected streams and rivers in South Brazil. Stud Neotrop Fauna Environ 40: 69-89.

CZERNIAWSKA-KUSZA I. 2005. Comparing modified biological monitoring working party score system and several biological indices based on macroinvertebrates for water-quality assessment. Limnologica 35: 169-176.

DAMANIK-AMBARITA MN ET AL. 2016. Ecological water quality analysis of the Guayas river basin (Ecuador) based on macroinvertebrates indices. Limnologica 57: 27-59.

DEMIRAK A, YILMAZ HA, KESKIN F, ŞAHIN Y \& AKPOLAT O. 2012. Investigation of heavy metal content in the suspended particulate matter and sediments of inner Gokova Bay and creeks. Envir Monit Assess 184: 7113-7124.

EGLER M, BUSS DF, MOREIRA JC \& BAPTISTA DF. 2012. Influence of agricultural land-use and pesticides on benthic macroinvertebrate assemblages in an agricultural river basin in southeast Brazil. Braz J Biol 72: 437-443.

ERBA S, PACE G, DEMARTINI D, DI PASQUALE D, DÖRFLINGER G \& BUFFAGNI A. 2015. Land use at the reach scale as a major determinant for benthic invertebrate community in Mediterranean rivers of Cyprus. Ecol Ind 48: 477-491. 
FAN W, XU Z \& WANG WX. 2014. Metal pollution in a contaminated bay: Relationship between metal geochemical fractionation in sediments and accumulation in a polychaete. Environ Pollut 191: 50-57.

FANNY C, VIRGINIE A, JEAN-FRANÇOIS F, JONATHAN B, MARIECLAUDE R \& SIMON D. 2013. Benthic indicators of sediment quality associated with run-of-river reservoirs. Hydrobiol 703: 149-164.

FERREIRA WR, PAIVA LT \& CALLISTO M. 2011. Development of a benthic multimetric index for biomonitoring of a neotropical watershed. Braz J Biol 71: 15-25.

FLORES-TENA FJ \& MARTÍNEZ-TABCHE L. 2001. The effect of chromium on the hemoglobin concentration of Limnodrilus hoffmeisteri (Oligochaeta: Tubificidae). Ecotoxicol Environ Saf 50: 196-202.

FLYNN SL, SZYMANOWSKI JES \& FEIN JB 2014. Modeling bacterial metal toxicity using a surface complexation approach. Chem Geol 374: 110-116.

FRAUENDORF TC, COLÓN-GAUD C, WHILES MR, BARNUM TR, LIPS KR, PRINGLE CM \& KILHAM SS. 2013. Energy flow and the trophic basis of macroinvertebrate and amphibian production in a neotropical stream food web. Freshw Biol 58: 1340-352.

FRIZZERA GL \& ALVES RG 2012. A influência da resolução taxonômica de Oligochaeta na avaliação da qualidade da água em um córrego urbano em Minas Gerais, Brasil. Acta Limnol Bras 24: 408-416.

GONÇALVES FB \& MENEZES MS. 2011. A comparative analysis of biotic indices that use macroinvertebrates to assess water quality in a coastal river of Paraná state, southern Brazil. Biota Neotrop 11: 27-36.

HE C, BARTHOLDY J \& CHRISTIANSEN C. 2012. Clay mineralogy, grain size distribution and their correlations with trace metals in the salt marsh sediments of the Skallingen barrier spit, Danish Wadden Sea. Environ Earth Sci 67: 759-769.

HE F, JIANG W, TANG T \& CAI Q. 2015. Assessing impact of acid mine drainage on benthic macroinvertebrates: can functional diversity metrics be used as indicators? J Freshwat Ecol 30: 513-524.

HEINO J. 2008. Patterns of functional biodiversity and function-environment relationships in lake littoral macroinvertebrates. Limnol Oceanogr 53: 1446-1455.

HUGHES MF 2002. Arsenic toxicity and potential mechanisms of action. Toxicology Letters 133: 1-16.
JOHNSON J, SCHEWEL L \& GRAEDEL TE. 2006. The Contemporary Anthropogenic Chromium Cycle. Envir Sci Tech 40: 7060-7069.

JONES FC. 2008. Taxonomic sufficiency: The influence of taxonomic resolution on freshwater bioassessments using benthic macroinvertebrates. Environ Rev 16: 45-69.

JONES JI, MURPHY JF, COLLINS AL, SEAR DA, NADEN PS \& ARMITAGE PD. 2012. The impact of fine sediment on macroinvertebrates: fine sediment and macro-invertebrates. River Res Appl 28: 1055-1071.

JUNQUEIRA VM \& CAMPOS SCM. 1998. Adaptation of "BMWP" method for water quality evaluation to rio das Velhas watershed (Minas Gerais, Brazil). Acta Limnol Bras 10: 125-135.

LAMPARELLI MC. 2004. Grau de trofia em corpos d'água do Estado de São Paulo: avaliação dos métodos de monitoramento. Tese de doutorado. Instituto de Biociências da Universidade de São Paulo, 238 p.

LINARES MS, FACCIOLI GG \& FREITAS LM. 2013. Benthic macroinvertebrate community structure and seasonal variation in a neotropical stream in the State of Alagoas, Brazil. Biota Neotrop 13: 50-54.

LOGAN M. 2010. Biostatistical design and analysis using R: a practical guide. UK: Willey-Blackwell, 577 p.

LONG ER, MACDONALD DD, SMITH SL \& CALDER FD. 1995. Incidence of adverse biological effects within ranges of chemical concentrations in marine and estuarine sediments. Envir Manag 19: 81-97.

LÓPEZ-DOVÁL JC, BARATA C \& DÍEZ S. 2015. El uso de organismos como indicadores de la contaminación y evaluación del riesgo sobre el ecosistema acuático en el embalse de Flix (Catalunya, Ne De España). In: Pompêo $M$ et al. (Eds), Ecologia de Reservatórios e Interfaces, São Paulo: Instituto de Biociências da Universidade de São Paulo p. 1-32.

LÓPEZ-DOVÁL JC, CASTRO-CATALÀ N, ANDRÉS-DOMÉNECH I, BLASCO J, GINEBREDA A \& MUÑOZ I. 2012. Analysis of monitoring programmes and their suitability for ecotoxicological risk assessment in four Spanish basins. Sci Total Envir 440: 194-203.

LORENZEN CJ. 1967. Determination of chlorophyll and pheo-pigments: spectrophotometric equations. Limnol Oceanogr 12: 343-346.

MACKINTOSH TJ, DAVIS JA \& THOMPSON RM. 2015. The influence of urbanisation on macroinvertebrate biodiversity in constructed stormwater wetlands. Sci Total Envir 536: 527-537. 
MANDAVILLE SM. 2002. Benthic macroinvertebrates in freshwaters - taxa tolerance values, metrics and protocols. Soil; water conservation society of metro Halifax: Canadá, 128 p.

MANSUR MCD, CALLIL CT, CARDOSO FR \& IBARRA JAA. 2004. Uma retrospectiva e mapeamento da invasão de espécies de Corbicula (Mollusca, Bivalvia, Veneroida, Corbiculidae) oriundas do Sudeste asiático na América do Sul. In: Silva JSV \& Souza RCCL (Org.), Água de lastro e bioinvasão, Rio de Janeiro, RJ: Editora Interciência, p. 39-58.

MARCHESE MR. 2009. Macroinvertebrados bentónicos sudamericanos. Sistemática y biología. In: Domingués E \& Fernández HR (Eds), Tucumán, Argentina: Fundación Miguel Lillo, p. 551-565.

MARTINS MVA ET AL. 2015. Early diagenesis and clay mineral adsorption as driving factors of metal pollution in sediments: the case of Aveiro Lagoon (Portugal). Envir Sci Pollut Res 22: 10019-10033.

MÉNDEZ-FERNÁNDEZ L, MARTÍNEZ-MADRID M \& RODRIGUEZ P. 2013. Toxicity and critical body residues of $\mathrm{Cd}, \mathrm{Cu}$ and $\mathrm{Cr}$ in the aquatic oligochaete Tubifex (Müller) based on lethal and sublethal effects. Ecotoxicol 22: 1445-1460.

MERRIT RW \& CUMMINS KW. 1996. An introduction to the aquatic insects of North America. Dubuque, IA: Kendall/ Hunt Publ. Co., 862 p.

MIAO S, DELAUNE RD \& JUGSUJINDA A 2006. Influence of sediment redox conditions on release/solubility of metals and nutrients in a Louisiana Mississippi River deltaic plain freshwater lake. Sci Total Environ 371: 334-343

MICHAHILOVA P, ILKOVA J \& WHITE KN. 2003. Functional and structural rearrangements of salivary gland polytene chromosomes of Chironomus riparius Mg. (Diptera, Chironomidae) in response to freshly neutralized aluminium. Environ Pollut 123: 193-207.

MILNER AM, WOODWARD A, FREILICH JE, BLACK RW \& RESH VH. 2016. Detecting significant change in stream benthic macroinvertebrate communities in wilderness areas. Ecol Ind 60: 524-537.

MUGNAI R, OLIVEIRA RB, CARVALHO AL \& BAPTISTA DF. 2008. Adaptation of the Indice Biotico Esteso (IBE) for water quality assessment in rivers of Serra do Mar, Rio de Janeiro State, Brazil. Trop Zool 21: 57-74.

NAIMAN RJ \& DÉCAMPS RH. 1997. The Ecology of interfaces: Riparian zones. Annu Rev Ecol Evol Syst 28: 621-658.

NELSON WA \& STEINMAN AD. 2013. Changes in the benthic communities of Muskegon Lake, a Great Lakes Area of Concern. J Great Lakes Res 39: 7-18.
OLIVEIRA PE, GOMES AR, SANCHES RC \& SAAD AR. 2008. Análise da evolução da paisagem no entorno da represa dos rios Jaguari e Jacareí, estado de São Paulo, com base em sensoriamento remoto e SIG. Geociências 27: 527-539.

PERSAUD D, JAAGUMAGI R \& HAYTON A. 1993. Guidelines for the protection and management of aquatic sediment quality in Ontario. Ontario: Queen's Printer of Ontario, $39 \mathrm{p}$.

PUIGAGUT J, CHAZARENC F \& COMEAU Y. 2014. Influence of tubificid worms on nutrient fluxes across watersediment interface in fish farm settling ponds. Knowl Manag Aquat Ecosyst 413: 12.

QIN BQ, GAO G, ZHU GW, ZHANG YL, SONG YZ, TANG XM, XU H \& DENG JM. 2013. Lake eutrophication and its ecosystem response. Chinese Sci Bull 58: 961-970.

QIN CY, ZHOU J, CAO Y, ZHANG Y, HUGHES RM \& WANG BX. 2014. Quantitative tolerance values for common stream benthic macroinvertebrates in the Yangtze River Delta, Eastern China. Envir Monit Assess 186: 5883-5895.

RANGEL CMA, BAPTISTA NETO JA, FONSECA EM, MCALISTER J \& SMITH BJ. 2011. Study of heavy metal concentration and partitioning in the Estrela River: implications for the pollution in Guanabara Bay - SE Brazil. An Acad Bras Cienc 83: 801-816.

ROIG N, SIERRA J, MORENO-GARRIDO I, NIETO E, GALLEGO EP, SCHUHMACHER M \& BLASCO J. 2016. Metal bioavailability in freshwater sediment samples and their influence on ecological status of river basins. Sci Total Envir 540: 287-296.

SABESP - COMPANHIA DE SANEAMENTO BÁSICO DO ESTADO DE SÃO PAULO. 2015. Boletim dos mananciais. Disponível em: http://site.sabesp.com.br/site/interna/Default. aspx?secaold=553. Acessado em nov/2015.

SCHARNWEBER K, SYVÄRANTA J, HILT S, BRAUNS M, VANNI MJ, BROTHERS S, KÖHLER J, KNEZEVIC-JARIC J \& MEHNER T. 2014. Whole-lake experiments reveal the fate of terrestrial particulate organic carbon in benthic food webs of shallow lakes. Ecol 95: 1496-1505.

SHANG J, LIAO Q, ZHANG L \& FAN C. 2014. The influence of different benthic fauna on inorganic nitrogen flux and denitrification in a large shallow hyper-eutrophic lake. Fundam Appl Limnol Arch Für Hydrobiol 184: 101-108.

SCHNEIDER IL, TEIXEIRA EC, RODRIGUES MLK \& ROLIM SBA. 2014. Metal content and distribution in surface sediments in an industrial region. An Acad Bras Cienc 86: 1043-1062.

SCHWARZENBACH RP, ESCHER BI, FENNER K, HOFSTETTER TB, JOHNSON CA, VON GUNTEN U \& WEHRLI B. 2006. The challenge 
of micropollutants in aquatic systems. Science 313: 1072-1077.

SCHWARZENBACH RP, EGLI T, HOFSTETTER TB, GUNTEN U \& WEHRLI B. 2010. Global water pollution and human health. Annu Rev Env Resour 35: 109-136.

SHUHAIMI-OTHMAN M, NADZIFAH Y, UMIRAH MS \& AHMAD AK. 2012. Toxicity of metals to an aquatic worm, Nais elinguis (Oligochaeta, Naididae). Res J Envir Toxicol 6: 122-132.

SHUHAIMI-OTHMAN M, YAKUB N, UMIRAH NS \& ABAS A. 2011. Toxicity of eight metals to Malaysian freshwater midge larvae Chironomus javanus (Diptera, Chironomidae). Toxicol Ind Health 27: 879-886.

SILVEIRA LS, MARTINS RT, DA SILVEIRA GA, GRAZUL RM, LOBO DP \& DA GAMA ALVES R. 2013. Colonization by Chironomidae larvae in decomposition leaves of Eichhornia azurea in a lentic system in southeastern Brazil. J Insect Sci 13: 20. SPRAGUE JB. 1970. Measurement of pollutant toxicity to fish. II. Utilizing and applying bioassay results. Water Res 4: 3-32.

SURIANO MT, FONSECA-GESSNER AA, ROQUE FO \& FROEHLICH CG. 2011. Choice of macroinvertebrate metrics to evaluate stream conditions in Atlantic Forest, Brazil. Envir Monit Assess 175: 87-101.

TAKAMURA N, ITO T, UENO R, OHTAKA A, WAKANA I, NAKAGAWA M, UENO Y \& NAKAJIMA H. 2009. Environmental gradients determining the distribution of benthic macroinvertebrates in Lake Takkobu, Kushiro wetland, northern Japan. Ecol Res 24: 371-381.

TANG KW, GLADYSHEV MI, DUBOVSKAYA OP, KIRILLIN G \& GROSSART HP. 2014. Zooplankton carcasses and nonpredatory mortality in freshwater and inland sea environments. J Plankton Res 36: 597-612.

TRIVINHO-STRIXINO S. 2011. Larvas de Chironomidae: guia de identificação. São Carlos, SP: gráfica da Universidade Federal de São Carlos, 371 p.

TUNDISI JG \& MATSUMURA-TUNDISI T. 2008. Limnologia. São Paulo: Oficina de Textos, $631 \mathrm{p}$.

USEPA - US ENVIRONMENTAL PROTECTION AGENCY. 1992. Method 3005A: Acid digestion of waters for total recoverable or dissolved metals for analysis by FLAA or ICP spectroscopy. 5 p. Available at: <https://www.epa. gov/sites/production/files/2015-12/documents/3005a. pdf> Accessed dec/2019.

USEPA - US ENVIRONMENTAL PROTECTION AGENCY. 1996. Method 3050B: Acid digestion of sediments, sludges, and soils. 12 p. Available at: <https://www.epa.gov/sites/ production/files/2015-06/documents/epa-3050b.pdf> Accessed dec/2019.

USEPA - US ENVIRONMENTAL PROTECTION AGENCY. 1999. Toxicity reference values: Screening level risk assessment protocol, 97 p. Available at: <https://archive. epa.gov/epawaste/hazard/tsd/td/web/pdf/appx-e.pdf> Accessed dec/2019.

VALDERRAMA JC. 1981. The simultaneous analysis of total nitrogen and phosphorus in natural waters. Marine Chem 10: 109-122.

WETZEL RG \& LIKENS GE. 1991. Limnological analysis. New York, W. B.: Saunders Company, 391 p.

WHATELY M \& CUNHA P. 2007. Cantareira 2006: um olhar sobre o maior manancial de água da Região Metropolitana de São Paulo. São Paulo: Instituto Socioambiental, $68 \mathrm{p}$.

WHITING DP, WHILES MR \& STONE ML. 2011. Patterns of macroinvertebrate production, trophic structure, and energy flow along a tallgrass prairie stream continuum. Limnol Oceanogr 56: 887-898.

YU J, LI Y, LIU X, LI K, CHEN F, GULATI R \& LIU Z. 2013. The fate of cyanobacterial detritus in the food web of Lake Taihu: a mesocosm study using $13 \mathrm{C}$ and $15 \mathrm{~N}$ labeling. Hydrobiol 710: 39-46.

ZHANG L \& LIU J. 2014. Relationships between ecological risk indices for metals and benthiccommunities metrics in a macrophyte-dominated lake. Ecol Ind 40: 162-174.

ZILLI FL, MONTALTO L \& MARCHESE MR. 2008. Benthic invertebrate assemblages and functional feeding groups in the Parana River floodplain (Argentina). Limnologica 38: 159-171.

ZUUR AF, IENO EN, WALKER NJ, SAVELIEV AA \& SMITH GM. 2009. Mixed effects models and extentions in Ecology with R. New York: Springer Sciences+Business Media, LLC, 574 p.

\section{How to cite:}

BEGHELLI FGS, CETRA M, MARCHESE M, LÓPEZ-DOVÁL JC, ROSA AH, POMPÊO MLM \& MOSCHINI-CARLOS V. 2020. Taxonomic and nontaxonomic responses of benthic macroinvertebrates to metal toxicity in tropical reservoirs. The case of Cantareira Complex, São Paulo, Brazil. An Acad Bras Cienc 92: e20180962. DOI 10.1590/0001-3765202020180962.

Manuscript received on September 12, 2018; accepted for publication on December 27, 2018

FREDERICO G.S. BEGHELLI ${ }^{1,2}$

https://orcid.org/0000-0002-7920-3083 


\section{MAURÍCIO CETRA ${ }^{3}$}

https://orcid.org/0000-0002-3902-0661

\section{MERCEDES MARCHESE ${ }^{4}$}

https://orcid.org/0000-0001-6027-9865

\section{JÚLIO CÉSAR LÓPEZ-DOVÁL ${ }^{5,6}$}

https://orcid.org/0000-0002-0090-8532

\section{ANDRÉ H. ROSA}

https://orcid.org/0000-0002-2042-018X

\section{MARCELO L. M. POMPÊO ${ }^{1,6}$}

https://orcid.org/0000-0002-5632-9257

\section{VIVIANE MOSCHINI-CARLOS ${ }^{1}$}

https://orcid.org/0000-0002-5832-912X

${ }^{1}$ Programa de Pós-Graduação em Ciências Ambientais, Instituto de Ciência e Tecnologia de Sorocaba/ICT, UNESP, Avenida Três de Março, 51, Aparecidinha, 18087-180 Sorocaba, SP, Brazil

${ }^{2}$ Programa de Graduação em Gestão Ambiental, Faculdade de Tecnologia do Estado de São Paulo/FATEC, Rua Dr. João Vieira de Camargo, 104, 18205-600 Itapetininga, SP, Brazil

${ }^{3}$ Universidade Federal de São Carlos/UFSCar, Rodovia João Leme dos Santos, SP 264, Km 110, Itinga,18052-780 Sorocaba, SP, Brazil ${ }^{4}$ Instituto Nacional de Limnología/INALI, Ciudad Universitaria, Paraje El Pozo, 3000, Santa Fe, Argentina

${ }^{5}$ Catalan Institute for Water Research/ICRA, Carrer Emili Grahit 101, 17003 Girona, Spain ${ }^{6}$ Departamento de Ecologia, Instituto de Biologia, Universidade de São Paulo/USP, Rua do Matão, 321, Butantã, 05508-090 São Paulo, SP, Brazil

Correspondence to: Frederico Guilherme de Souza Beghelli E-mail:fred_sb@hotmail.com

\section{Author contributions}

Each author presented relevant contribution to elaboration of the present manuscript as fallows:

Dr. Frederico Beghelli: data sampling, analysis and interpretation. The main responsible for the final text.

Dr. Maurício Cetra: statystical analyses and its interpretation. Dr. Marcedes Marchese: identification and Taxonomy. Dr. Júlio López-Dovál: collaboration on data sampling, metodology and discussion of the results. Ecotoxicological approach.

Dr. André Rosa: collaboration and review of procedures related to Chemical Analysis and the interpretation of results
Dr. Marcelo Pompêo and Dr. Viviane Moschini-Carlos: sampling design, methodology and discussion of the results. They supervised the development of this work.

\section{(c) BY}

